\title{
14. HETEROGENEITY OF OCEANIC PERIDOTITE FROM THE WESTERN CANYON WALL AT MARK: RESULTS FROM SITE $920^{1}$
}

\author{
Christopher J. Stephens ${ }^{2}$
}

\begin{abstract}
Drilling on the western canyon wall of the Mid-Atlantic Ridge south of the Kane Fracture Zone $\left(23^{\circ} \mathrm{N}\right.$ at MARK) penetrated $200 \mathrm{~m}$ into serpentinized spinel peridotite exposed in the footwall of a low-angle, east-dipping, normal fault system. A total penetration of $320 \mathrm{~m}$ was achieved in two holes (Holes 920B and 920D), from which recovery averaged approximately $48 \%$. This degree of recovery is unique in sampling of oceanic peridotite. These holes thus represent an opportunity to examine not only the mineralogical and bulk composition of in situ oceanic peridotite, but also the degree and character of any heterogeneity in those parameters.

Mineral compositions in peridotite are remarkably uniform, considering the large apparent modal heterogeneity. The peridotites were classified during shipboard studies as predominantly harzburgite and orthopyroxene-rich harzburgite (orthopyroxene ranging up to 35 modal\%) with volumetrically minor dunite and lherzolite. $\mathrm{Mg}$ numbers in olivine and orthopyroxene average 90.7 , consistent with the peridotites being moderately depleted in terms of the previously identified, regional variation in North Atlantic oceanic peridotite mineralogy. Chrome spinel is correspondingly $\mathrm{Al}_{2} \mathrm{O}_{3}$-rich $(\mathrm{Cr} /[\mathrm{Cr}+\mathrm{Al}] \sim 28)$, and orthopyroxene contains moderate $\mathrm{Al}_{2} \mathrm{O}_{3}$ and $\mathrm{Cr}_{2} \mathrm{O}_{3}$ contents.

Trace-element analyses of whole-rock samples using inductively coupled plasma mass spectrometry indicate that "background" peridotites have very low abundances of high-field-strength elements, with $\mathrm{Y}<1 \mathrm{ppm}$ and $\mathrm{Zr}$ averaging about $60 \mathrm{ppb}$. $\mathrm{Nb}$ and $\mathrm{Ta}$ abundances are less than $\sim 30 \mathrm{ppb}$, and typically are $<10 \mathrm{ppb}$. Chondrite-normalized rare-earth element (REE) patterns show strong depletions in light rare-earth elements (LREE $<10^{-3}$ times chondrite). REE abundances in the most depleted compositions are consistent with the harzburgite forming the residue to $15 \%$ to $20 \%$ fractional melting, approaching clinopyroxene exhaustion, of a fertile lherzolite. Erratic enrichment in LREE that is not reflected in changes in mineral major-element chemistry is consistent with selective enrichment of the peridotites by a fluid rich in LREE and, to a lesser extent, Zr. Selective enrichment is suggested to have accompanied the infiltration of melt through the peridotite, although textural or mineral chemistry evidence for melt infiltration is not preserved.
\end{abstract}

\section{INTRODUCTION}

The mineralogy and composition of peridotites collected from seafloor exposures at mid-ocean ridges must reflect an integrated history of melt/mantle reaction during ascent of the mantle column. Current models for mantle uplift below zones of seafloor spreading (Klein and Langmuir, 1987; Langmuir et al., 1993; McKenzie and Bickle, 1988; Forsyth, 1993) suggest that the uplift history should be relatively similar for any localized mid-ocean ridge segment, but may vary significantly along the length of a ridge on the scale of as little as tens of kilometers.

There are differences of degree attributed to factors affecting the degree of melt extraction during upwelling, depending on whether the model is an active or passive one. The primary influences on the degree of melt extraction, however, are differences in the mantle potential temperature, expressed as the geothermal gradient (Klein and Langmuir, 1987), and differences in the uplift history as a function of the rate of spreading (Forsyth, 1993), which influences the amount of heat loss through conduction. Both of these factors can vary from place to place, but also over time at any one location, such that the geochemical evolution of any mantle sample reflects an integrated, dynamic history of upwelling.

Away from spreading centers, the thickness and depth below sea level of oceanic crust are independent of spreading rate, and can be

IKarson, J.A., Cannat, M., Miller, D.J., and Elthon, D. (Eds.), 1997. Proc, ODP, Sci. Results, 153: College Station, TX (Ocean Drilling Program).

${ }^{2}$ Department of Earth Sciences, The University of Queensland, Brisbane, 4072, Australia. Present address: School of Geology, Queensland University of Technology, 2 George Street, Brisbane, 4000, Australia. stephens@earthsciences.uq.edu.au modeled in terms of thermal models for cooling crust as a function of age (Parsons and Sclater, 1977). Modeling of the elevation profiles over spreading centers, however, (Parsons and Sclater, 1977; Klein and Langmuir, 1987) shows that, at least for other than very slow spreading ridges, the depth below sea level to the top of the ridge can be modeled to the first approximation in terms of variations of the upper mantle temperature, both with depth and laterally away from the ridge. These observations suggest that, in terms of magmatic production and the resultant ridge and ocean-floor physiography, mid-ocean ridges respond relatively rapidly to minimize the effects of changes in upwelling dynamics. The question posed here is whether these changes result in mineralogical and geochemical heterogeneity in underlying mantle that has been subjected to changes in rates of processes during its history of upwelling.

In addition to the effects of melt extraction, the composition of lithospheric mantle is able to be modified by the addition of melt in varying ways. The bulk composition of peridotite can be modified by the incorporation of residues after closure of pathways during melt passage (Dick, 1989; Elthon, 1992; Takahashi, 1992; Hess, 1993). At levels above the peridotite solidus, there is likely to be insufficient heat to reequilibrate these residues, and they may retain their coherence as petrographically recognizable segregations. Dick (1989) argued that the abundance of plagioclase as a modal component in oceanic peridotite reflected melt infiltration and the capture of residual melt during vein closure.

At depths corresponding to the lithosphere, however, there may be sufficient latent heat and dynamic stress for melt pods to reequilibrate with the surrounding peridotite although such pods may remain, at least for a short time, as chemically enriched zones. Recognition of these pods may be difficult, although olivine websterite retrieved by 
Dick et al. (1984) from dredge hauls in the MARK area and clinopyroxene-rich pods such as those observed in Cores 153-920D-13R and $15 \mathrm{R}$ (Kempton and Stephens, this volume) may be examples of this process occurring.

It is now widely argued that geochemical effects of mantle-derived refertilization processes, which do not require the capture of a melt fraction, can be observed in a range of ophiolitic, oceanic, and alpine-type peridotites (Navon and Stolper, 1987; Bodinier et al., 1990; Cannat et al., 1990; Elthon, 1992; Takazawa et al., 1992). Evidence for this enrichment lies principally in the interpretation of concave-upward, chondrite-normalized, rare-earth-element (REE) patterns in whole-rock and clinopyroxene analyses, although Elthon (1992) cited evidence in the anomalous $\mathrm{Na}_{2} \mathrm{O}$ abundances in oceanic peridotite when compared with compositions calculated from fractional melting models (Johnson et al., 1990). Hekinian et al. (1989) argued for the existence of mantle heterogeneity on the basis of variations in the chemistry of off-axis basalts from the East Pacific Rise.

There is thus considerable conjecture as to the scale of interactions that occur below mid-ocean ridges in terms of melt extraction and subsequent selective or bulk mass addition during upwelling. On a regional scale, the averaged variations in mineral, modal, and calculated bulk peridotite major- and trace-element compositions are shown to be consistent with melt extraction under a combination of passive and dynamic factors (Dick et al., 1984; Michael and Bonatti, 1985, Klein and Langmuir, 1987, Forsyth, 1993). Hess (1993), Niu and Batiza (1993), and Niu et al. (1995), nonetheless, have pointed out that crystallization of olivine is an inevitable consequence of adiabatic melt migration to shallower depths, and this should be reflected in modal chemistry. Good correlations between bulk chemistry and trace-element chemistry on a local scale should support simple models of fractional melting during upwelling as the major interaction between mantle and melt, whereas poor correlations may support models invoking widespread refertilization.

Onboard investigations argued for the modally heterogeneous nature of the of the Site 920 peridotite, suggesting that the peridotite had undergone a complex history of melt extraction (Shipboard Scientific Party, 1995). This paper presents mineral chemistry for 30 samples plus modal, whole-rock major- and trace-element data for 21 samples of peridotite from Site 920 . The relation between these data sets is explored, and the trace-element data are used to argue for the peridotite having been impregnated with a fluid enriched in light REE (LREE), for which there is no observed petrographic or major-element expression.

\section{ANALYTICAL DATA}

Samples for this study were collected throughout Holes 920B and $920 \mathrm{D}$ (Fig. 1) with the aim of sampling as wide a range of modal compositions as possible. As a result, the data presented here cannot be considered volumetrically representative of the peridotite mass drilled. Onboard studies (Shipboard Scientific Party, 1995), nonetheless, showed that harzburgite with 10 to 20 modal\% orthopyroxene was the overwhelmingly abundant rock type, with very minor lherzolite and dunite. Although the samples analyzed here generally reflect this pattern, no attempt has been made to infer that the bulk average of these compositions accurately reflects a bulk average for the MidAtlantic Ridge south of the Kane Fracture Zone (MARK) area. The same constraints should also be seen as applying to results of other studies referenced in this paper.

Modal data is widely regarded as difficult to collect for oceanic peridotites because of their coarse-grained, porphyroclastic texture (Dick et al., 1984), generally high degree of serpentinization, and problems relating to sample size. Dick et al. (1984) and Michael and Bonatti (1985) have, nonetheless, argued that pseudomorphic textures in serpentinite are faithful reproductions of the primary mineralogy and mineral modes.
Modal data quoted here are based on similar petrographic criteria to those studies. The author's observations support the findings of those authors in that, except in localized deformation zones, there is no petrographic evidence for strain having developed because of volume changes either associated with, or after, serpentinization. Although the criteria for the distinction of orthopyroxene from clinopyroxene is regarded as difficult in heavily serpentinized rocks, there appeared to be a clear petrographic distinction in the samples examined. Clinopyroxene pseudomorphs were recognized by the presence of coarse, oxide-rich, exsolution lamellae and strain twinning, and by the tendency for the grains to have coarse, interstitial (holly leaf), textural relationships. Pseudomorphs after orthopyroxene are typically recognizable by the even replacement of relatively coarse grain sizes by bastite. Olivine pseudomorphs reflect equant subgrain textures with radial serpentine textures within subgrains and high abundances of fine-grained magnetite production. Crosscutting veins of serpentine were excluded from modal counts.

Given the sampling constraints on both size of sample and Ocean Drilling Program (ODP) policy with regard to core holes, the estimation of modal compositions from core samples (typically $\sim 50 \mathrm{~cm}^{3}$ as $50 \times 25 \mathrm{~cm}$ quarter cores or $40 \times 57 \mathrm{~cm}$ slabs cut from the half core face) is a somewhat more acute problem than from samples acquired by dredging, the most common method by which oceanic peridotite has been retrieved in the past. In this study, modal compositions were calculated after measuring 2000 points per sample on standard $25 \times$ $50 \mathrm{~mm}\left(12.5 \mathrm{~cm}^{2}\right)$ polished sections cut predominantly from quarter cores. This point density was chosen to provide an accurate map of each section, including chrome spinel, which has a grain-size range of $0.1-2 \mathrm{~mm}$.

Despite attempts to minimize errors in the modal estimates, the data presented here should be interpreted with some caution, given ambiguities in both the assignment of the mineral type and in the problem of thin-section size and orientation. The sampling density compares favorably with the 400 points per $8 \mathrm{~cm}^{2}$ measured by Michael and Bonatti (1985), although less favorably with the 2400 points per $24 \mathrm{~cm}^{2}$ measured by Dick et al. (1984). Both of those studies examined data from dredge samples collected from sites on the Mid-Atlantic Ridge and Indian Ocean ridge systems, and data for each locality were presented as averaged data for all of the measured samples from each site. This approach reflected the regional nature of those studies, and the number of measured samples from any one site ranged from 1 to 16 samples although, in both studies, the most common number of samples was between 1 and 7 .

Mineral compositions were measured by wavelength-dispersive spectrometry using a four-channel JEOL JXA-8800L Superprobe housed at the Centre for Microscopy and Microanalysis at The University of Queensland. Counting times were chosen to achieve better than $0.5 \%$ standard deviation across the range of analyzed elements for measured abundances greater than $1 \%$. The procedure was standardized against a combination of natural and synthetic standards (Table 1), and results were calculated with the proprietary JEOL ZAF correction routine.

Olivine and spinel compositions were measured using the minimum beam diameter (nominally $1 \mu \mathrm{m}$ for a $\sim 2$ - to $2.5-\mu \mathrm{m}$-diameter source volume). Traversing of grains did not detect core-rim variations that could be ascribed to primary compositional variations. Pyroxene grains were measured using both minimum and $15-\mu \mathrm{m}$-diameter beam sizes. Expanding the beam diameter to $15 \mu \mathrm{m}$ did not significantly reduce the effects of compositional variation caused by low temperature exsolution of the corresponding orthopyroxene or clinopyroxene, which occurs on the scale that varies from finer than the resolution of the scanning electron microscope $(<1 \mu \mathrm{m})$ to several microns. Note that the configuration of the JEOL Superprobe is such that the counting windows are exposed to only a 10- $\mu \mathrm{m}$-wide and 40$\mu \mathrm{m}$-long window on the sample, and that using beam diameters greater than $\sim 15 \mu \mathrm{m}$ will compromise the accuracy of the measurement.

Although strictly flawed in principle, expansion of the beam diameter, sometimes to diameters of $100 \mu \mathrm{m}$ or more, is widely used as 
Hole 920B

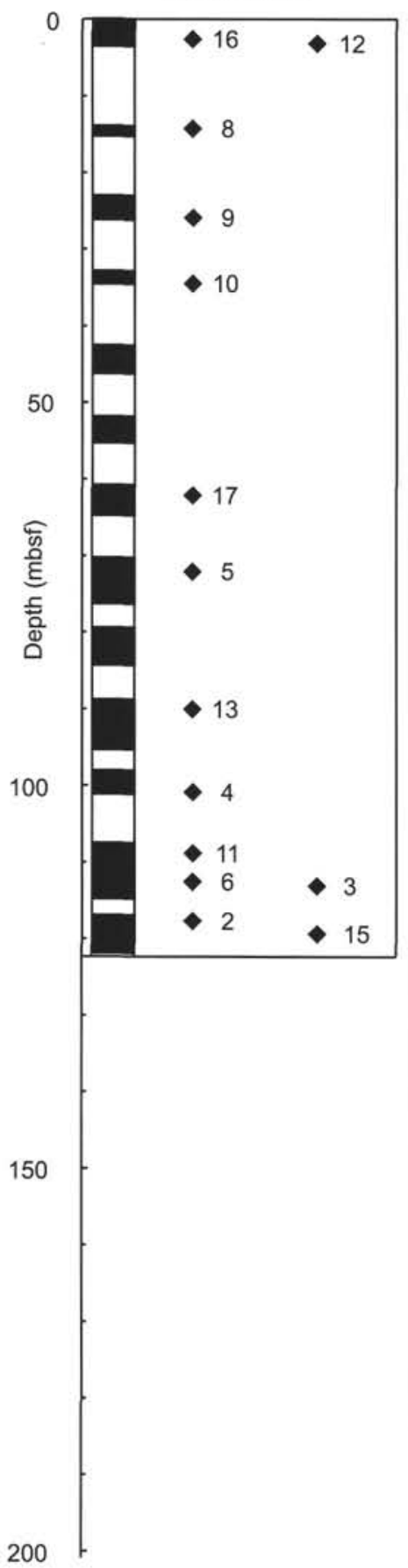

Hole 920D

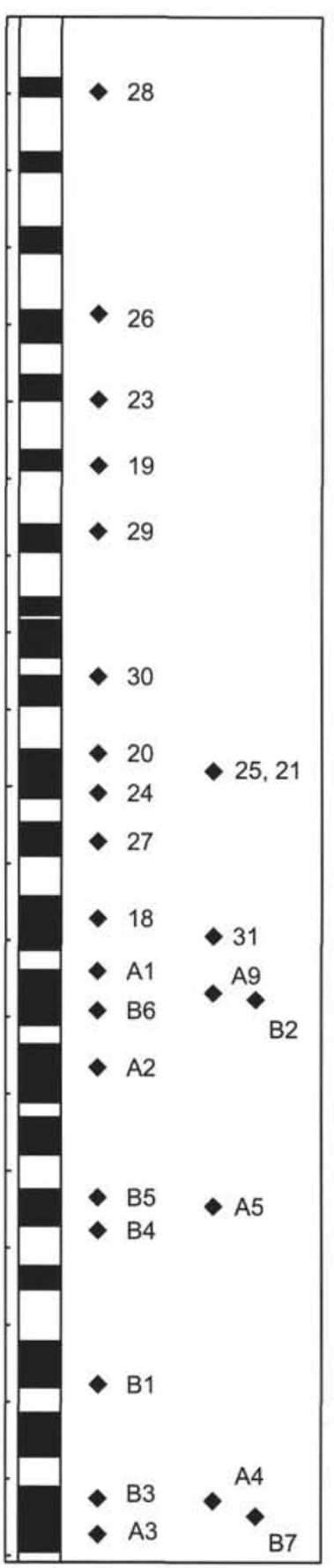

\begin{tabular}{|c|c|}
\hline 153-920B-13R-1, 66- $72 \mathrm{~cm}$ & 2 \\
\hline $153-920 \mathrm{~B}-12 \mathrm{R}-5,18-23 \mathrm{~cm}$ & 3 \\
\hline 153-920B-11R-2, $92-99 \mathrm{~cm}$ & 4 \\
\hline 153-920B-8R-2, $58-63 \mathrm{~cm}$ & 5 \\
\hline $153-920 \mathrm{~B}-12 \mathrm{R}-4,84-90 \mathrm{~cm}$ & 6 \\
\hline $153-920 \mathrm{~B}-2 \mathrm{R}-1,20-26 \mathrm{~cm}$ & 8 \\
\hline 153-920B-3R-2, $82-89 \mathrm{~cm}$ & 9 \\
\hline 153-920B-4R-1, $129-136 \mathrm{~cm}$ & 10 \\
\hline $153-920 \mathrm{~B}-12 \mathrm{R}-1,132-135 \mathrm{~cm}$ & 11 \\
\hline $153-920 \mathrm{~B}-1 \mathrm{~W}-3,70-73 \mathrm{~cm}$ & 12 \\
\hline $153-920 \mathrm{~B}-10 \mathrm{R}-1,102-108 \mathrm{~cm}$ & 13 \\
\hline $153-920 \mathrm{~B}-13 \mathrm{R}-2,107-114 \mathrm{~cm}$ & 15 \\
\hline $153-920 \mathrm{~B}-1 \mathrm{~W}-2,138-142 \mathrm{~cm}$ & 16 \\
\hline 153-920B-7R-1, $131-135 \mathrm{~cm}$ & 17 \\
\hline $153-920 D-14 R-3,7-12 \mathrm{~cm}$ & 18 \\
\hline 153-920D-7R-2, $71-78 \mathrm{~cm}$ & 19 \\
\hline $153-920 \mathrm{D}-12 \mathrm{R}-1,73-78 \mathrm{~cm}$ & 20 \\
\hline $153-920 \mathrm{D}-12 \mathrm{R}-3,29-35 \mathrm{~cm}$ & 21 \\
\hline 153-920D-6R-3, 63- 68cm & 23 \\
\hline $153-920 \mathrm{D}-12 \mathrm{R}-5,36-43 \mathrm{~cm}$ & 24 \\
\hline $153-920 \mathrm{D}-12 \mathrm{R}-3,35-39 \mathrm{~cm}$ & 25 \\
\hline 153-920D-5R-2, 76- $82 \mathrm{~cm}$ & 26 \\
\hline 153-920D-13R-3, 31- $36 \mathrm{~cm}$ & 27 \\
\hline 153-920D-2R-2, 33- 38cm & 28 \\
\hline $153-920 \mathrm{D}-8 \mathrm{R}-1,103-110 \mathrm{~cm}$ & 29 \\
\hline $153-920 D-11 R-1,29-33 \mathrm{~cm}$ & 30 \\
\hline $153-920 \mathrm{D}-14 \mathrm{R}-4,76-82 \mathrm{~cm}$ & 31 \\
\hline 153-920D-15R-1, $8-15 \mathrm{~cm}$ & $\mathrm{~A} 1$ \\
\hline $153-920 \mathrm{D}-16 \mathrm{R}-3,64-70 \mathrm{~cm}$ & A2 \\
\hline $153-920 \mathrm{D}-22 \mathrm{R}-5,11-116 \mathrm{~cm}$ & $\mathrm{~A} 3$ \\
\hline $153-920 \mathrm{D}-22 \mathrm{R}-3,19-23 \mathrm{~cm}$ & A4 \\
\hline $153-920 \mathrm{D}-18 \mathrm{R}-2,35-41 \mathrm{~cm}$ & A5 \\
\hline $153-920 \mathrm{D}-15 \mathrm{R}-3,36-40 \mathrm{~cm}$ & A9 \\
\hline $153-920 D-20 R-5,54-60 \mathrm{~cm}$ & B1 \\
\hline $153-920 \mathrm{D}-15 \mathrm{R}-3,114-119 \mathrm{~cm}$ & B2 \\
\hline 153-920D-22R-2, $69-73 \mathrm{~cm}$ & B3 \\
\hline $153-920 \mathrm{D}-18 \mathrm{R}-4,86-93 \mathrm{~cm}$ & B4 \\
\hline $153-920 \mathrm{D}-18 \mathrm{R}-1,73-79 \mathrm{~cm}$ & B5 \\
\hline 153-920D-15R-5, $14-22 \mathrm{~cm}$ & B6 \\
\hline 153-920D-22R-5, 3- $9 \mathrm{~cm}$ & B7 \\
\hline
\end{tabular}

Figure 1. Distribution of samples studied in this paper relative to the recovery (black columns to the left of each hole) for Holes 920B and 920D. Table on right defines sample codes used on figure.

a technique of averaging out the compositional segregation caused by exsolution in pyroxene. In terms of the technique, this approach relies on the assumption that the variation in the absorption of source volume seen by spectrometers is insignificant at the scale measured. Although this may be a reasonable assumption for orthopyroxene and clinopyroxene, there may be errors caused by the different ray paths seen by different spectrometer orientations relative to the orientation of the lamellae. In a geological sense, the technique relies on the inference that the redistribution of elements during low-temperature, subsolidus equilibration is limited within the host grain. As a result, it is common practice to only analyze cores of exsolved grains, al- though this can be difficult, especially for clinopyroxene, where the grain size is not large. Dick et al. (1984) applied a different approach in hand-picking grains of pyroxene and fusing them prior to analysis.

Both of these practices are arguably effective in achieving the aim of characterizing the higher temperature and pressure composition of the mineral. Lamellae-free margins to pyroxene grains clearly indicate that migration of cations up to the range of $1 \mathrm{~mm}$ occurs. The effect of exsolution on pyroxene analyses during this study was to give a wide range of $\mathrm{CaO}$ contents, and hence wollastonite (Wo):enstatite (En) ratios, for any set of analyses. Nonetheless, the contained weight percentages of oxides commonly regarded as significant in petroge- 
Table 1. Operating and calibration conditions for microprobe analysis of mineral phases in peridotite from Holes 920B and 920D.

\begin{tabular}{|c|c|c|c|}
\hline Element & Crystal & Channel & Standard \\
\hline $\mathrm{Si}$ & TAP & 3 & Wollastonite.t \\
\hline $\mathrm{Ti}$ & PET & 2 & $\mathrm{TiO}_{2 . \mathrm{t}}$ \\
\hline $\mathrm{Al}$ & TAP & 3 & Lake County Plagioclase \\
\hline $\mathrm{Cr}$ & PET & 2 & Chromite.t \\
\hline $\mathrm{Fe}$ & LIFH & 4 & $\mathrm{Fe}, \mathrm{O}_{3}, \mathrm{t}$ \\
\hline $\mathrm{Mn}$ & LIFH & 4 & Spessartine.t \\
\hline $\mathrm{Ni}$ & LIFH & 4 & $\mathrm{Ni}$ Olivine \\
\hline $\mathrm{Mg}$ & TAP & 3 & $\mathrm{MgO} . \mathrm{t}$ \\
\hline $\mathrm{Ca}$ & PET & 2 & Wollastonite.t \\
\hline $\mathrm{Na}$ & TAP & $i$ & Amelia Albite.t \\
\hline $\mathrm{K}$ & PET & 2 & Orthoclase.t \\
\hline
\end{tabular}

Notes: LIFH refers to LIF mounted on high Rowland Circle spectrometer. Standards denoted as " $t$ " indicate standards mounted on George Taylor Block. Accelerating potential was $15 \mathrm{kV}$, and the beam current was $15 \mathrm{nA}$. Na and $\mathrm{K}$ were standardized using a $10-\mu \mathrm{m}$ beam diameter.

netic studies of residual pyroxenes (e.g., $\mathrm{Al}_{2} \mathrm{O}_{3}$ and $\mathrm{Cr}_{2} \mathrm{O}_{3}$ ) varied sympathetically, and independently of $\mathrm{CaO}$ (Figs. 2A, 2B), suggesting that any of the generally practiced methods of averaging would not enhance the quality of the data. Nonetheless, coarse lamellae were avoided during measurement, and analyses in which $\mathrm{CaO}$ was $<19.5 \%$ for clinopyroxene and $>3 \%$ in orthopyroxene were excluded from the data reduction. The data are presented here as averages for individual samples, and are based on between 1 and 27 analyses from each sample.

Powders for major- and trace-element analysis were prepared by grinding all surfaces to cleanliness using silicon carbide powder on glass plates to remove any contamination resulting from contact with drilling or cutting apparatus. Blocks were then washed in alcohol and Milli-Q water in an ultrasonic bath to remove any organic or particulate contaminants. Large blocks were broken down in a carbon-steel percussion mill prior to pulverizing in a hardened steel TEMA mill. Checks on this method of preparation indicate that contamination in hard media (quartz) is restricted to less than $350 \mathrm{ppb} \mathrm{Sc}, \mathrm{V}$, and Co, and approximately $2.5 \mathrm{ppm} \mathrm{Cu}$, levels far below the natural abundances in these rocks ( $>4 \mathrm{ppm}$ ). Contamination of $\mathrm{Nb}$ and $\mathrm{Ta}$ is at the 1 to $3 \mathrm{ppb}$ detection level, which, although comparable in absolute levels to some of the analyzed peridotites, is regarded as a maximum, given the differences in hardness of quartz relative to serpentinized peridotite.

Whole-rock major-element, $\mathrm{Ni}$ and $\mathrm{Cr}$ abundances were analyzed on a Phillips PW140 XRF, and other trace elements were analyzed on a Fisons Quadrupole inductively coupled plasma mass spectrometer (ICP-MS), at the Department of Earth Sciences, The University of Queensland. The ICP-MS is housed in a high-quality clean laboratory with trace-element blank levels less than $0.1 \mathrm{ppb}$. Analytical quality was monitored against the international standards BIR-1 and PCC-1.

Note that in both major- and trace-element analyses, dissolution of chrome spinel remains an ongoing problem that is not yet resolved. The consequences of this in terms of analyses are not yet fully understood. It is unlikely to significantly effect $\mathrm{Al}_{2} \mathrm{O}_{3}$ contents, given the low modal abundances of spinel, but $\mathrm{Nb}$ and $\mathrm{Ta}$ abundances may be affected. There is, nonetheless, no evidence to suggest that the $\mathrm{Nb} / \mathrm{Ta}$ ratio may change as a result of their incomplete dissolution, and the interpretations reported here are not considered to be compromised by this problem.

\section{RESULTS}

Modal data for 21 MARK peridotites (Table 2) suggest that they are predominantly harzburgite, averaging 82.5 modal $\%$ olivine + serpentine, $15.3 \%$ orthopyroxene, $2.1 \%$ clinopyroxene, and $1 \%$ chrome spinel. This average contains significantly more olivine (cf. $75 \%$ ),
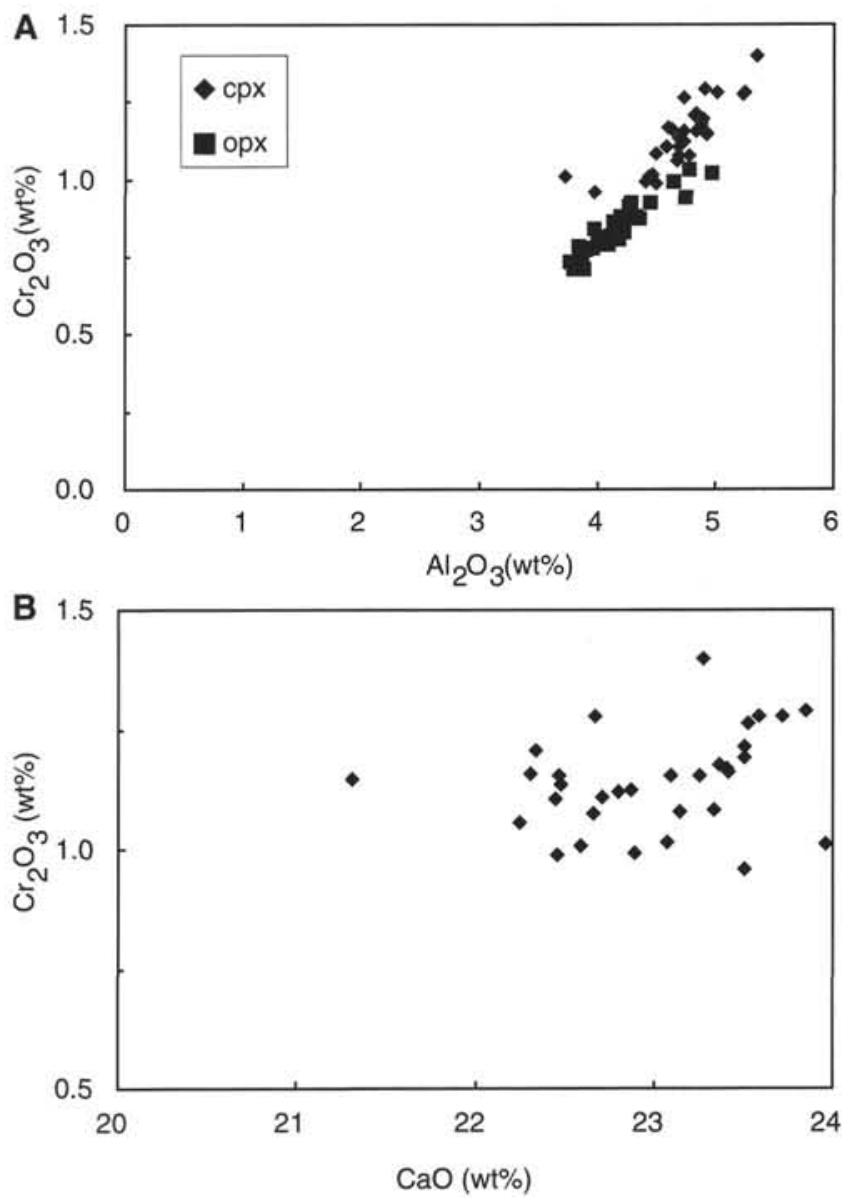

Figure 2. A. The distribution of $\mathrm{Al}_{2} \mathrm{O}_{3}$ and $\mathrm{Cr}_{2} \mathrm{O}_{3}$ in average microprobe analyses of clinopyroxene and orthopyroxene from Site 920. Note the expected good correlation and slightly lower abundances of both elements in orthopyroxene. B. $\mathrm{Cr}_{2} \mathrm{O}_{3}$ vs. $\mathrm{CaO}$ in clinopyroxene. Note the poor correlation. These graphs together indicate that orthopyroxene exsolution does not degrade microprobe analyses for minor elements despite the obvious effect on the ternary pyroxene components.

and perhaps spinel (cf. $0.5 \%$ ), relative to the average of oceanic peridotite samples computed by Dick et al. (1984). This suggests that Site 920 peridotites are mineralogically depleted compared with the Atlantic-Indian average oceanic peridotite. Two samples are modally estimated as lherzolite and three samples as dunite, the latter being completely serpentinized except for trace abundances of spinel. The degree of serpentinization ranges from $35 \%$ to $100 \%$ for silicate minerals.

The typical texture of the peridotites is porphyroclastic, defined by elongate orthopyroxene grains up to $1.5 \mathrm{~cm}$ in length (Shipboard Scientific Party, 1995). Fresh olivine is found as subgrain aggregates surrounding the orthopyroxene grains and, where unaltered, forms an equigranular subgrain mosaic after parent grains up to $3 \mathrm{~mm}$ in size. Given the ease with which olivine recrystallizes, these parent grain sizes are unlikely to have any significance. Clinopyroxene forms interstitial grains that rarely exceed $2 \mathrm{~mm}$ in size. Chrome spinel ranges in color from deep brown to honey brown, and ranges from 0.1 to $2 \mathrm{~mm}$ in size. Clinopyroxene and spinel commonly occur as trails cutting across the porphyroclastic fabric. Trace amounts of nickel sulfide and pyrite, the latter probably introduced during serpentinization, were observed.

Despite the apparent modal heterogeneity of the Site 920 peridotite, there is no determinable variation in mineral composition either with modal composition or across the range of measured composi- 
Table 2. Modal compositions of peridotite from Holes 920B and 920D.

\begin{tabular}{|c|c|c|c|c|c|}
\hline $\begin{array}{l}\text { Core, section, } \\
\text { interval }(\mathrm{cm})\end{array}$ & Serpentinization & Olivine & Orthopyroxene & Clinopyroxene & Spinel \\
\hline \multicolumn{6}{|l|}{ 153-920B- } \\
\hline $13 \mathrm{R}-1,66-72$ & 79.40 & 2.00 & 16.90 & 1.20 & 0.50 \\
\hline $12 \mathrm{R}-5,18-23$ & 71.50 & 22.40 & 1.70 & 0.90 & 3.50 \\
\hline $12 \mathrm{R}-4,84-90$ & 84.20 & 0.00 & 9.40 & 6.30 & 0.10 \\
\hline $2 \mathrm{R}-1,20-26$ & 67.10 & 4.00 & 28.50 & 0.00 & 0.40 \\
\hline $12 \mathrm{R}-1,132-135$ & 99.70 & 0.00 & 0.00 & 0.00 & 0.30 \\
\hline $10 \mathrm{R}-1,102-108$ & 82.20 & 0.80 & 15.80 & 0.00 & 1.20 \\
\hline $7 \mathrm{R}-1,131-135$ & 100.00 & 0.00 & 0.00 & 0.00 & 0.00 \\
\hline \multicolumn{6}{|l|}{$153-920 \mathrm{D}-$} \\
\hline $14 \mathrm{R}-3,7-12$ & 35.10 & 41.50 & 17.80 & 5.10 & 0.50 \\
\hline $12 \mathrm{R}-3,29-35$ & 79.00 & 4.80 & 14.10 & 1.20 & 0.90 \\
\hline $12 R-5,36-43$ & 100.00 & 0.00 & 0.00 & 0.00 & 0.00 \\
\hline $12 R-3,35-39$ & 79.30 & 2.30 & 15.10 & 2.50 & 0.80 \\
\hline $5 R-2,76-82$ & 83.20 & 0.00 & 12.10 & 2.70 & 2.00 \\
\hline $2 \mathrm{R}-2,33-38$ & 82.40 & 3.90 & 11.70 & 0.70 & 1.30 \\
\hline $14 R-4,76-82$ & 47.00 & 23.30 & 26.10 & 3.20 & 0.40 \\
\hline 15R-1, 8-15 & 61.00 & 9.40 & 26.60 & 2.40 & 0.60 \\
\hline $16 \mathrm{R}-3,64-70$ & 70.40 & 8.20 & 16.60 & 3.50 & 1.30 \\
\hline $22 \mathrm{R}-5,11-116$ & 76.80 & 1.30 & 18.60 & 2.20 & 1.10 \\
\hline $18 \mathrm{R}-2,35-41$ & 73.60 & 0.90 & 24.20 & 0.60 & 0.70 \\
\hline $22 \mathrm{R}-2,69-73$ & 76.80 & 13.00 & 4.45 & 3.65 & 2.10 \\
\hline $15 R-5,14-22$ & 79.60 & 6.50 & 10.30 & 2.50 & 1.10 \\
\hline $22 R-5,3-9$ & 51.90 & 7.80 & 36.60 & 3.20 & 0.50 \\
\hline
\end{tabular}

tions for the Site 920 peridotites. Olivine compositions are extremely consistent, typically $0.36 \%-0.40 \% \mathrm{NiO}$, and have consistent $\mathrm{Mg}$ numbers $(\mathrm{Mg} \#=\mathrm{Mg} / \Sigma[\mathrm{Mg}+\mathrm{Fe}])$ of $90.7 \pm 0.5$ (Table 3). Pyroxene compositions are indistinguishable in terms of their principal components (Fig. 3; Tables 4, 5); orthopyroxene has Mg\# values similar to coexisting olivine, and clinopyroxene has consistently higher $\mathrm{Mg} \#$ around 93. Chrome spinel (Table 6) has $\mathrm{Cr} \#(\mathrm{Cr} / \Sigma[\mathrm{Cr}+\mathrm{Al}])$ values about 28, and shows a limited range of 25 to 29 (Fig. 4). Not surprisingly, $\mathrm{Al}_{2} \mathrm{O}_{3}$ and $\mathrm{Cr}_{2} \mathrm{O}_{3}$ in pyroxene are well correlated, with slightly higher values of both oxides in clinopyroxene. $\mathrm{Cr} \#$ values in clinopyroxene and orthopyroxene are, nonetheless, relatively constant at 0.140 and 0.115 , respectively.

The Site 920 data were plotted in terms of components sensitive to the degree of melt extraction (Mysen and Kushiro, 1977; Jacques and Green, 1980) vs. the Mid-Atlantic Ridge data set of Michael and Bonatti (1985) in Figure 4. The Site 920 data consistently plot in the middle of the range on all plots, suggesting that the Site 920 peridotites are "moderately depleted" in a regional sense. This contrasts with the modal data that suggest the Site 920 peridotites are olivine rich, and hence modally depleted relative to Mid-Atlantic Ridge and Southwest Indian Ridge peridotites.

\section{GEOCHEMISTRY Major Elements}

Comparison of major-element data (Tables 7,8) based on calculated compositions of peridotites is clearly complicated by the inherent inaccuracy in estimating modes and in the accuracy of analysis of minor elements in pyroxene by electron microprobe. A comparison of the measured and calculated $\mathrm{MgO}$ contents for 20 Site 920 peridotites shows this (Fig. 5A), illustrating not only that the calculated $\mathrm{MgO}$ content is dominated by the, perhaps inaccurate, estimated modal olivine content, but also that measured compositions are significantly more homogeneous in $\mathrm{MgO}$, except for dunites.

This relative homogeneity is further illustrated by the tight clustering of the measured compositions in terms of their $\mathrm{Mg}-\mathrm{Al}$ variations (Fig. 5B), which should reflect the depletion of aluminous pyroxene relative to olivine. The Site 920 data define a tight cluster, which reinforces that the modal estimates must be in error. Only two samples of dunite are clearly distinguished on this plot, emphasizing that the optical estimation of modes in grain-size-reduced and serpentinized peridotites must be undertaken with caution.

The measured Site 920 compositions are comparable with calculated compositions for American-Antarctic Ridge/Southwest Indian
Ridge peridotites from the Bullard and Islas Orcadis Fracture Zones (Table 7,8), consistent with the relative compositions of the mineral phases. They are clearly less depleted in pyroxene than samples from $43^{\circ} \mathrm{N}$ (Fig. 5B), consistent with the inferred higher degrees of depletion of the $43^{\circ} \mathrm{N}$ peridotite from their high $\mathrm{Cr} \#$ in spinel (45 to 55; Shibata and Thompson, 1986).

\section{Trace Elements}

Trace-element analyses (Table 9) were obtained on rock types modally categorized as ranging from dunite to lherzolite. Of the large-ion-lithophile elements, $\mathrm{Rb}$ abundances are variable, ranging from 6 to $110 \mathrm{ppb}$. Ba shows a large range of abundances, from 43 to $702 \mathrm{ppb}$, which probably reflects serpentinization and addition from seawater, as evidenced by a relatively strong correlation with Cs (Fig. $6 \mathrm{~A}) . \mathrm{Sr}$ is generally constant at $2-4 \mathrm{ppm}$ except for one anomalous sample containing $98 \mathrm{ppm}$ that was found to contain a spinel-plagioclase veinlet. $\mathrm{Sr} / \mathrm{Zr}$ ratios show a relatively good correlation with $\mathrm{Zr}$, defining two populations of different negative slope and inflection at about $60 \mathrm{ppb} \mathrm{Zr}$ (Fig. 6B). The significance of this correlation is unclear, but it is unlikely to be reflecting the introduction of $\mathrm{Sr}$ in seawater given the correlation with a high-field-strength element (HFSE).

The abundances of HFSEs are variable: $\mathrm{Zr}$ ranges from about 30 to $200 \mathrm{ppb}$, and $\mathrm{Y}$ from 320 to $720 \mathrm{ppb}$. Nb abundances are very low, ranging from 2 to $14 \mathrm{ppb}$ and thus approach the levels of depletion occurring in some of the most depleted island-arc systems (e.g., the Lau-Tonga arc system; A. Ewart unpubl. data). HFSE abundances correlate poorly both with each other and with REE, suggesting that the processes effecting their abundances are not systematic. Ta abundances are very low (most samples have less than $10 \mathrm{ppb} \mathrm{Ta}$ ), but range up to $24 \mathrm{ppb}$. Although the precision of these values is excellent, the accuracy is questionable because there is no systematic behavior in $\mathrm{Nb} / \mathrm{Ta}$ ratios. $\mathrm{Zr} / \mathrm{Hf}$ ratios vary systematically from values of 5 up to about 25 as $\mathrm{Zr}$ increases from about 30 to $196 \mathrm{ppb}$ (Fig. $6 \mathrm{C})$.

The analyses can be organized according to their REE patterns into four different groups (Fig. 7). A group of LREE-depleted samples patterns shows moderately negative-sloping, chondrite-normalized patterns for the heavy REEs (HREEs), Eu, and Sm, and steep patterns with negative slopes for the elements $\mathrm{La}-\mathrm{Nd}$. HREE abundances range from 0.1 to $1 \times$ chondrite, and $\mathrm{Sm}_{\mathrm{N}}$ and $\mathrm{Eu}_{\mathrm{N}}$, from 0.7 to 0.9 (LREE-depleted group; Fig. 7A). La and $\mathrm{Ce}$ are below the detection limit of the ICP-MS (1-3 ppb) for most of the samples within this group. A notable feature of this group is the sudden depletion in 


\begin{tabular}{|c|c|c|c|c|c|c|c|c|c|c|c|c|c|c|c|c|c|}
\hline Hole: & 153-920B & 153-920B & 153-920B & 153-920B & 153-920B & 153-920B & 153-920B & 153-920B & $153-920 \mathrm{~B}$ & $153-920 \mathrm{~B}$ & 153-920B & 153-920D & 153-920D & 153-920D & 153-920D & 153-920D & $153-920 \mathrm{D}$ \\
\hline Core, section: & 13R-1 & $12 \mathrm{R}-5$ & $12 \mathrm{R}-4$ & $13 \mathrm{R}-2$ & 2R-1 & $3 \mathrm{R}-2$ & $4 R-1$ & IW-3 & 10R-1 & $12 \mathrm{R}-5$ & $13 \mathrm{R}-2$ & $14 \mathrm{R}-3$ & $7 \mathrm{R}-2$ & $12 \mathrm{R}-1$ & $12 \mathrm{R}-3$ & $6 \mathrm{R}-3$ & $12 \mathrm{R}-3$ \\
\hline Interval $(\mathrm{cm})$ : & $66-72$ & $18-23$ & $84-90$ & $114-120$ & $20-26$ & $82-89$ & $129-136$ & $70-73$ & $102-108$ & $23-28$ & $107-114$ & $7-12$ & $71-78$ & 73-78 & 29-35 & $63-68$ & $35-39$ \\
\hline$n:$ & 7 & 5 & 2 & 11 & 4 & 1 & 9 & 7 & 9 & 4 & 10 & 18 & 13 & 10 & 13 & 14 & 2 \\
\hline $\mathrm{SiO}_{2}$ & 41.44 & 41.08 & 40.78 & 40.88 & 41.72 & 41.48 & 41.84 & 41.12 & 41.49 & 41.50 & 40.88 & 41.20 & 41.42 & 41.60 & 41.07 & 41.43 & 41.25 \\
\hline $\mathrm{TiO}_{2}^{2}$ & 0.01 & 0.01 & 0.00 & 0.01 & 0.02 & 0.04 & 0.01 & 0.01 & 0.01 & 0.01 & 0.01 & 0.01 & 0.02 & 0.01 & 0.00 & 0.00 & 0.02 \\
\hline $\mathrm{Al}_{2} \mathrm{O}_{3}$ & 0.01 & 0.02 & 0.01 & 0.01 & 0.01 & 0.02 & 0.02 & 0.01 & 0.01 & 0.02 & 0.01 & 0.01 & 0.00 & 0.01 & 0.01 & 0.01 & 0.01 \\
\hline $\mathrm{Cr}_{2} \mathrm{O}_{3}$ & 0.02 & 0.02 & 0.03 & 0.01 & 0.11 & 0.00 & 0.02 & 0.02 & 0.01 & 0.01 & 0.01 & 0.01 & 0.01 & 0.01 & 0.01 & 0.00 & 0.01 \\
\hline $\mathrm{FeO}$ & 9.03 & 9.12 & 9.20 & 8.99 & 8.60 & 9.08 & 8.94 & 9.14 & 9.17 & 9.27 & 9.04 & 9.36 & 9.29 & 9.27 & 9.06 & 9.15 & 9.25 \\
\hline $\mathrm{MnO}$ & 0.13 & 0.12 & 0.14 & 0.13 & 0.14 & 0.17 & 0.14 & 0.14 & 0.14 & 0.14 & 0.13 & 0.13 & 0.13 & 0.13 & 0.13 & 0.13 & 0.12 \\
\hline $\mathrm{NiO}$ & 0.36 & 0.38 & 0.37 & 0.37 & 0.39 & 0.38 & 0.39 & 0.38 & 0.38 & 0.38 & 0.38 & 0.37 & 0.40 & 0.37 & 0.39 & 0.38 & 0.35 \\
\hline $\mathrm{MgO}$ & 50.13 & 50.22 & 48.82 & 49.05 & 50.49 & 50.55 & 50.45 & 50.29 & 50.40 & 50.37 & 49.30 & 49.92 & 50.43 & 50.51 & 49.38 & 50.28 & 50.08 \\
\hline $\mathrm{CaO}$ & 0.05 & 0.04 & 0.05 & 0.02 & 0.04 & 0.05 & 0.03 & 0.03 & 0.03 & 0.04 & 0.02 & 0.04 & 0.02 & 0.03 & 0.02 & 0.03 & 0.03 \\
\hline $\mathrm{Na}_{2} \mathrm{O}$ & 0.01 & 0.00 & 0.02 & 0.01 & 0.00 & 0.00 & 0.00 & 0.00 & 0.01 & 0.01 & 0.00 & 0.01 & 0.01 & 0.01 & 0.00 & 0.00 & 0.02 \\
\hline $\mathrm{K}_{2} \mathrm{O}$ & 0.00 & 0.01 & 0.01 & 0.01 & 0.00 & 0.00 & 0.00 & 0.00 & 0.00 & 0.00 & 0.00 & 0.00 & 0.00 & 0.00 & 0.01 & 0.00 & 0.00 \\
\hline $\mathrm{Si}$ & 1.001 & 0.995 & 1.004 & 1.004 & 1.002 & 0.996 & 1.003 & 0.995 & 0.998 & 0.998 & 1.001 & 0.998 & 0.996 & 0.998 & 1.003 & 0.999 & 0.998 \\
\hline $\mathrm{Ti}$ & 0.000 & 0.001 & 0.000 & 0.000 & 0.001 & 0.001 & 0.000 & 0.001 & 0.002 & 0.000 & 0.002 & 0.003 & 0.004 & 0.001 & 0.000 & 0.001 & 0.000 \\
\hline $\mathrm{Al}$ & 0.000 & 0.000 & 0.000 & 0.000 & 0.000 & 0.001 & 0.000 & 0.000 & 0.000 & 0.001 & 0.000 & 0.000 & 0.000 & 0.000 & 0.000 & 0.000 & 0.000 \\
\hline $\mathrm{Cr}$ & 0.000 & 0.000 & 0.000 & 0.000 & 0.000 & 0.000 & 0.000 & 0.000 & 0.000 & 0.000 & 0.000 & 0.000 & 0.000 & 0.000 & 0.000 & 0.000 & 0.000 \\
\hline $\mathrm{Fe}^{2+}$ & 0.182 & 0.185 & 0.190 & 0.185 & 0.173 & 0.182 & 0.179 & 0.185 & 0.184 & 0.187 & 0.185 & 0.190 & 0.187 & 0.186 & 0.185 & 0.184 & 0.187 \\
\hline $\mathrm{Mn}$ & 0.002 & 0.003 & 0.003 & 0.003 & 0.003 & 0.003 & 0.003 & 0.003 & 0.003 & 0.003 & 0.003 & 0.003 & 0.003 & 0.002 & 0.003 & 0.003 & 0.003 \\
\hline $\mathrm{Ni}$ & 0.007 & 0.007 & 0.007 & 0.007 & 0.008 & 0.007 & 0.00 & 0.007 & 0.007 & 0.008 & 0.008 & 0.007 & 0.008 & 0.007 & 0.0 & 0.008 & 0.007 \\
\hline $\mathrm{Mg}$ & 1.804 & 1.813 & 1.791 & 1.796 & 1.808 & 1.810 & 1.803 & 1.813 & 1.807 & 1.805 & 1.800 & 1.802 & 1.808 & 1.807 & 1.798 & 1.807 & 1.806 \\
\hline $\mathrm{Ca}$ & 0.001 & 0.001 & 0.002 & 0.001 & 0.001 & 0.001 & 0.001 & 0.001 & 0.001 & 0.001 & 0.001 & 0.001 & 0.001 & 0.001 & 0.001 & 0.001 & 0.001 \\
\hline $\mathrm{Na}$ & 0.000 & 0.000 & 0.001 & 0.000 & 0.000 & 0.000 & 0.000 & 0.000 & 0.000 & 0.000 & 0.000 & 0.000 & 0.000 & 0.000 & 0.000 & 0.000 & 0.001 \\
\hline $\mathrm{K}$ & 0.000 & 0.000 & 0.000 & 0.000 & 0.000 & 0.000 & 0.000 & 0.000 & 0.000 & 0.000 & 0.000 & 0.000 & 0.000 & 0.000 & 0.000 & 0.000 & 0.000 \\
\hline $\mathrm{Mg} \#$ & 90.8 & 90.7 & 90.4 & 90.7 & 91.3 & 90.9 & 91.0 & 90.7 & 90.7 & 90.6 & 90.7 & 90.5 & 90.6 & 90.7 & 90.7 & 90.7 & 90.6 \\
\hline
\end{tabular}

Notes: Averages are for all analyses from each sample filtered for $\mathrm{CaO}>19.5 \%$. Data are in weight percent (wt $\%$ ); $n=$ number of analyses; molecular formula was calculated for $\mathrm{O}=6$.

Table 3 (continued).

\begin{tabular}{|c|c|c|c|c|c|c|c|c|c|c|c|c|c|c|c|c|}
\hline Hole: & $153-920 \mathrm{D}$ & $153-920 \mathrm{D}$ & $153-920 \mathrm{D}$ & $153-920 \mathrm{D}$ & $153-920 \mathrm{D}$ & $153-920 \mathrm{D}$ & 153-920D & $153-920 \mathrm{D}$ & I53-920D & $153-920 \mathrm{D}$ & $153-920 \mathrm{D}$ & 153-920D & $153-920 \mathrm{D}$ & $153-920 \mathrm{D}$ & $153-920 \mathrm{D}$ & Average \\
\hline Core, section: & SR-2 & $2 \mathrm{R}-2$ & $14 R-4$ & $15 \mathrm{R}-1$ & $16 \mathrm{R}-3$ & $22 \mathrm{R}-5$ & $22 \mathrm{R}-3$ & $18 R-2$ & $15 \mathrm{R}-3$ & $20 R-5$ & $15 \mathrm{R}-3$ & $22 \mathrm{R}-2$ & $18 R-4$ & $15 \mathrm{R}-5$ & $22 \mathrm{R}-5$ & \\
\hline Interval $(\mathrm{cm})$ : & $76-82$ & $33-38$ & $76-82$ & $8-15$ & $64-70$ & $11-116$ & $19-23$ & $35-41$ & $36-40$ & $54-60$ & $114-119$ & $69-73$ & $86-93$ & $14-22$ & $3-9$ & \\
\hline$n:$ & 5 & 11 & 18 & 13 & 22 & 13 & 19 & 5 & 9 & 16 & 13 & 17 & 12 & 13 & 14 & 376 \\
\hline $\mathrm{SiO}_{2}$ & 40.09 & 41.56 & 41.17 & 40.85 & 41.35 & 41.22 & 41.08 & 41.18 & 41.27 & 41.12 & 40.95 & 40.76 & 41.54 & 40.98 & 40.29 & 41.17 \\
\hline $\mathrm{TiO}_{2}^{2}$ & 0.00 & 0.01 & 0.01 & 0.01 & 0.01 & 0.01 & 0.01 & 0.00 & 0.01 & 0.01 & 0.01 & 0.01 & 0.01 & 0.02 & 0.01 & 0.01 \\
\hline $\mathrm{Al}_{2} \mathrm{O}_{3}$ & $\begin{array}{l}0.01 \\
0.01\end{array}$ & $\begin{array}{l}0.01 \\
0.00\end{array}$ & $\begin{array}{l}0.01 \\
0.01\end{array}$ & $\begin{array}{l}0.01 \\
0.00\end{array}$ & $\begin{array}{l}0.01 \\
0.02\end{array}$ & $\begin{array}{l}0.01 \\
0.01\end{array}$ & $\begin{array}{l}0.01 \\
0.01\end{array}$ & $\begin{array}{l}0.00 \\
0.02\end{array}$ & $\begin{array}{l}0.01 \\
0.01\end{array}$ & $\begin{array}{l}0.01 \\
0.01\end{array}$ & $\begin{array}{l}0.02 \\
0.01\end{array}$ & $\begin{array}{l}0.01 \\
0.02\end{array}$ & 0.01 & $\begin{array}{l}0.02 \\
0.02\end{array}$ & 0.02 & 0.01 \\
\hline $\begin{array}{l}\mathrm{Cr}_{2} \mathrm{O}_{3} \\
\mathrm{FeO}\end{array}$ & $\begin{array}{l}0.01 \\
9.25\end{array}$ & $\begin{array}{l}0.00 \\
9.52\end{array}$ & $\begin{array}{l}0.01 \\
9.09\end{array}$ & $\begin{array}{l}0.00 \\
9.25\end{array}$ & $\begin{array}{l}0.02 \\
9.04\end{array}$ & $\begin{array}{l}0.01 \\
8.96\end{array}$ & $\begin{array}{l}0.01 \\
9.05\end{array}$ & $\begin{array}{l}0.02 \\
9.19\end{array}$ & $\begin{array}{l}0.01 \\
9.22\end{array}$ & $\begin{array}{l}0.01 \\
9.04\end{array}$ & $\begin{array}{l}0.01 \\
9.45\end{array}$ & $\begin{array}{l}0.02 \\
9.03\end{array}$ & $\begin{array}{l}0.01 \\
9.43\end{array}$ & $\begin{array}{l}0.02 \\
9.02\end{array}$ & $\begin{array}{l}0.01 \\
9.17\end{array}$ & $\begin{array}{l}0.01 \\
9.15\end{array}$ \\
\hline $\mathrm{MnO}$ & 0.13 & 0.13 & 0.13 & 0.13 & 0.13 & 0.13 & 0.13 & 0.14 & 0.13 & 0.13 & 0.12 & 0.12 & 0.15 & 0.13 & 0.14 & 0.13 \\
\hline $\mathrm{NiO}$ & 0.38 & 0.37 & 0.37 & 0.38 & 0.38 & 0.38 & 0.38 & 0.39 & 0.44 & 0.38 & 0.38 & 0.38 & 0.39 & 0.38 & 0.40 & 0.38 \\
\hline $\mathrm{MgO}$ & $\begin{array}{r}50.45 \\
\end{array}$ & 50.46 & 50.25 & $\begin{array}{r}49.98 \\
49.98\end{array}$ & $\begin{array}{r}50.66 \\
\end{array}$ & 50.14 & $\begin{array}{r}49.91 \\
\end{array}$ & 50.02 & 50.04 & 50.19 & 49.97 & $\begin{array}{r}49.80 \\
\end{array}$ & 50.81 & 50.23 & 49.26 & 50.06 \\
\hline $\mathrm{CaO}$ & 0.04 & $\begin{array}{r}5.40 \\
0.03\end{array}$ & 0.04 & $\begin{array}{r}4.98 \\
0.04\end{array}$ & 0.06 & $\begin{array}{r}0.14 \\
0.03\end{array}$ & $\begin{array}{r}4.91 \\
0.06\end{array}$ & $\begin{array}{r}5.02 \\
0.04\end{array}$ & 0.04 & 0.02 & 0.06 & $\begin{array}{r}4.80 \\
0.04\end{array}$ & 0.04 & 0.04 & 0.05 & $\begin{array}{r}0.04 \\
0.04\end{array}$ \\
\hline $\mathrm{Na}_{2} \mathrm{O}$ & 0.01 & 0.01 & 0.01 & 0.01 & 0.02 & 0.00 & 0.04 & 0.01 & 0.02 & 0.01 & 0.01 & 0.02 & 0.01 & 0.01 & 0.01 & 0.01 \\
\hline $\mathrm{K}_{2} \mathrm{O}$ & 0.01 & 0.00 & 0.00 & 0.01 & 0.01 & 0.01 & 0.01 & 0.00 & 0.01 & 0.00 & 0.01 & 0.01 & 0.01 & 0.00 & 0.01 & 0.01 \\
\hline $\mathrm{Si}$ & 0.980 & 0.997 & 0.996 & 0.994 & 0.994 & 0.998 & 0.998 & 0.997 & 0.998 & 0.996 & 0.993 & 0.995 & 0.994 & 0.994 & 0.993 & 0.997 \\
\hline $\mathrm{Ti}$ & & 0.003 & & & & 0.001 & 0.005 & 0.000 & 0.002 & 0.00 & 0.0 & 0.0 & 0.002 & 0.003 & 0.000 & 0.053 \\
\hline $\mathrm{Al}$ & 0.000 & 0.000 & 0.000 & 0.000 & 0.000 & 0.000 & 0.000 & 0.000 & 0.001 & 0.00 & 0.0 & 0.000 & 0.000 & 0.001 & 0.001 & 0.000 \\
\hline $\mathrm{Cr}$ & 0.000 & 0.000 & 0.000 & 0.000 & 0.000 & 0.000 & 0.000 & 0.000 & 0.000 & 0.000 & 0.06 & 0.000 & 0.000 & 0.000 & 0.000 & 0.000 \\
\hline $\mathrm{Fe}^{2+}$ & 0.189 & 0.191 & 0.184 & 0.188 & 0.182 & 0.182 & 0.184 & 0.186 & 0.186 & 0.183 & 0.192 & 0.184 & 0.189 & 0.183 & 0.189 & 0.185 \\
\hline $\mathrm{Mn}$ & 0.002 & 0.003 & 0.003 & 0.003 & 0.003 & 0.003 & 0.003 & 0.003 & 0.003 & 0.003 & 0.003 & 0.003 & 0.003 & 0.003 & 0.003 & 0.003 \\
\hline $\mathrm{Ni}$ & 0.007 & 0.007 & 0.007 & 0.007 & 0.007 & 0.007 & 0.007 & 0.008 & 0.008 & 0.008 & 0.007 & 0.007 & 0.008 & 0.007 & 0.008 & 0.007 \\
\hline $\mathrm{Mg}$ & $\begin{array}{l}.037 \\
1.839\end{array}$ & 1.804 & 1.812 & 1.812 & 1.816 & 1.810 & 1.807 & 1.806 & $\begin{array}{l}1.804 \\
\end{array}$ & $\begin{array}{l}1.812 \\
1.812\end{array}$ & 1.807 & $\begin{array}{l}.0712 \\
1.812\end{array}$ & 1.812 & 1.816 & $\begin{array}{l}0.811 \\
1.811\end{array}$ & 1.808 \\
\hline $\mathrm{Ca}$ & 0.001 & 0.001 & 0.001 & 0.001 & $\begin{array}{l}1.010 \\
0.002\end{array}$ & 0.001 & 0.002 & 0.001 & 0.001 & 0.001 & 0.002 & 0.001 & 0.001 & 0.001 & 0.001 & 0.001 \\
\hline $\mathrm{Na}$ & 0.000 & 0.000 & 0.000 & 0.000 & 0.001 & 0.000 & 0.002 & 0.000 & 0.001 & 0.000 & 0.000 & 0.001 & 0.000 & 0.000 & 0.000 & 0.000 \\
\hline $\mathrm{K}$ & 0.000 & 0.000 & 0.000 & 0.000 & 0.000 & 0.000 & 0.000 & 0.000 & 0.000 & 0.000 & 0.000 & 0.000 & 0.000 & 0.000 & 0.000 & 0.000 \\
\hline Mg\# & 90.7 & 90.4 & 90.8 & 90.6 & 90.9 & 90.9 & 90.8 & 90.7 & 90.6 & 90.8 & 90.4 & 90.8 & 90.6 & 90.9 & 90.5 & 90.7 \\
\hline
\end{tabular}




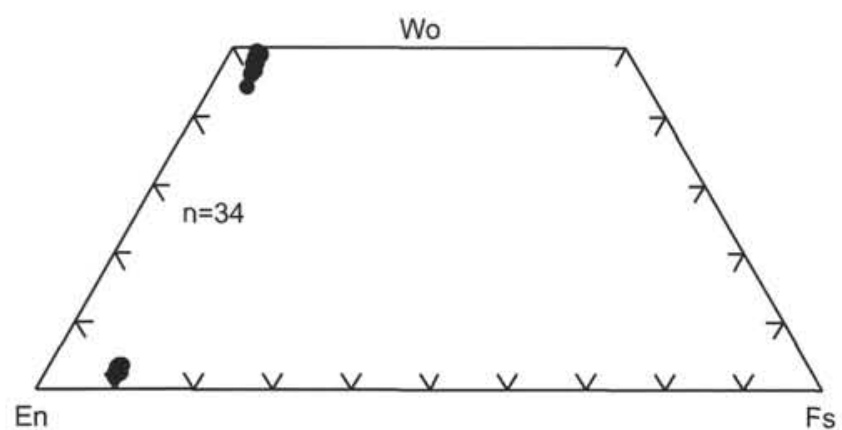

Figure 3. Average clinopyroxene and orthopyroxene microprobe compositions on a per sample basis for Site 920 peridotites. Data are cut for $\mathrm{CaO}>$ $19.5 \%$ in clinopyroxene and $\mathrm{CaO}<3 \%$ in orthopyroxene to remove the effects of $\mathrm{CaO}$ variation caused by exsolution. Wo $=$ wollastonite, $\mathrm{En}=$ enstatite, $\mathrm{Fs}=$ ferrosilite.

LREE for the elements La-Nd. The group contains rocks that have modal abundances of orthopyroxene ranging from 14.1 to 28.5 modal\% orthopyroxene, although all but one have modal orthopyroxene greater than $18 \%$, and modal clinopyroxene ranging up to $3.65 \%$. The extent of REE depletion cannot, therefore, be related directly to the apparent modal mineralogy.

The LREE-depleted pattern can be modeled for residual compositions calculated for $15 \%-22 \%$ fractional melting of fertile spinel peridotite. The steeper LREE pattern evident in the peridotites may be either a function of the sensitivity of the analytical technique at the very low levels of LREE, the choice of distribution coefficients in melting models, or real depletions, but is not easily constrained at this time. It is notable that, in this model, the residual clinopyroxene abundances fell below 3 modal\% for $15 \%$ melting, and all clinopyroxene is exhausted at about $22 \%$ melting.

A second group of Site 920 peridotites (HREE-depleted; Fig. 7B) shows flatter, more-depleted, HREE patterns, with strong depletions in LREE $(<0.003 \times$ chondrite $)$ and moderate-to-strong, positive Eu anomalies. Note that the greatest variation in the smoothness of the profiles is in Eu, which is present in abundances of $1-10 \mathrm{ppb}$ for most samples, and therefore is most susceptible to inaccuracies in the analytical determination. Both of these samples are completely serpentinized granular dunite.

Members of the third group of peridotites have similar HREE patterns to the first group, but are comparatively enriched in $\mathrm{La}, \mathrm{Ce}$, and $\operatorname{Pr}$ (LREE-enriched-1 group; Fig. 7C), and are transitional in their nature to a group that have even higher LREE abundances.

The last identified group of peridotites displays relatively flat REE patterns, in which REEs between $\mathrm{Sm}$ and $\mathrm{Yb}$ are indistinguishable from the first three groups (Fig. 8), but $\mathrm{La}, \mathrm{Ce}, \mathrm{Pr}$, and $\mathrm{Nd}$ are relatively enriched to levels of up to $0.2 \times$ chondrite $\left(\mathrm{La}_{N} / \mathrm{Yb}_{\mathrm{N}}\right.$ up to 0.25; LREE-enriched-2 group; Fig. 7D).

The comparatively enriched character of the LREE-enriched-2 group of samples is also reflected in the $\mathrm{Zr}$ abundances, containing from 71 to $166 \mathrm{ppb} \mathrm{Zr}$, compared with typical ranges of $30-86$ for the other groups. Even this correlation is not a strong one, however, because the highest $\mathrm{Zr}$ abundances are in samples that occur in the Laenriched-1 group (182 ppb; A5), and in a dunite in the HREE-depleted group (196 ppb; 11).

REE patterns such as observed here (Johnson et al., 1990; Dostal and Muecke, 1977; Pallister and Knight, 1981; Prinzhofer and Allègre, 1985), characterized by V-shaped inflections in the chondritenormalized patterns in the middle REE, have been modeled in terms of chromatographic metasomatism (Navon and Stolper, 1987; Bodinier et al., 1990; Takazawa et al., 1992). This mechanism of enrichment can account for the selective enrichment of some elements over others based on their relative incompatibility, and may account here for the erratic behavior of the HFSE. Modeling by Navon and Stolper (1987) suggests that low levels of enrichment of REE and inflections in the chondrite-normalized REE patterns at $\mathrm{Nd}$ to $\mathrm{Sm}$ are indicative of starved metasomatism, consistent with the absence of any majorelement mineral chemical reflection of the process.

Although evidence for rare interstitial magmatic clinopyroxene is present in some samples of Site 920 peridotite (e.g., Shipboard Scientific Party, 1995; Casey, this volume), magmatic clinopyroxene is unlikely to have the sufficiently high $\mathrm{La}_{\mathrm{N}} / \mathrm{Yb}_{\mathrm{N}}\left(>10^{2}\right)$ required such that small $(<<1 \%)$ modal abundances could significantly increase the LREE $_{\mathrm{N}}$ values, while not effecting the HREE $\mathrm{N}_{\mathrm{N}}$ values. On this basis, the presence of interstitial mineral grains as the site for the enriched components is considered unlikely. Trace-element data on clinopyroxene (Ross and Elthon, Chapter 13, this volume) also show no evidence for significant LREE enrichment, and the physical location of the enriched component thus remains speculative.

\section{DISCUSSION}

In contrast to shipboard observations that there is a significant variation in the modal composition of Site 920 peridotites, mineral chemistry, major-, and trace-element data suggest that the these rocks are compositionally homogeneous. The mineral compositions fall consistently within the range predicted from regional variations based on dredge, and limited drill, recoveries. The cause of the apparent modal layering must then reflect grain-size reduction in distinct layers during deformation (Ceuluneer and Cannat, this volume; Fletcher, Ceuleneer, et al., this volume), and subsequent masking of the fine-grained mineralogy by serpentinization.

The depth at which this deformation occurs should be generally, although not exclusively, able to be constrained to relatively shallow depths because of the association of some fine-grained zones with evidence of melt extraction and/or passage, such as veins and dikes of pyroxenite and gabbro (sensu lato). Features such as these must intrude at shallow depths to persist as discrete entities to the base of the crust (Ceuleneer and Raboniwicz, 1993). The homogeneous composition of mineral phases in peridotite, including spinel in crosscutting "trails," however, suggests that the bulk chemistry of the peridotite, except for minor true dunite, reflects homogenization at depths within the mantle corresponding to those close to the solidus. It is thus likely that later veins have utilized existing granular inhomogeneities, and are unrelated to the grain-size reduction process.

There is abundant evidence for subsolidus processes operating that could have affected the chemistry of individual components, or the overall geochemistry, of the system. Low-temperature reequilibration of the mineral chemistry is reflected in the development of exsolution lamellae and "granule exsolution" (Shipboard Scientific Party, 1995). These textures, and evidence for subsolidus element mobility, are particularly evident for clinopyroxene, and range from the presence of exsolution lamellae-free rims on clinopyroxene, to $\sim 0.5 \mathrm{~mm}$ blebs within orthopyroxene grains, and to the development of equigranular mosaics of clinopyroxene along subgrain boundaries.

The abundance of plagioclase-bearing dikelets, the occurrence of trails of spinel with low $\mathrm{Cr} \#$, apatite, and rarely plagioclase, crosscutting the predominant foliation, and the occurrence of patches containing apatite, zircon, and chlorite within the Site 920 peridotites (Shipboard Scientific Party, 1995) attest to the fact that fluids enriched in incompatible elements have infiltrated the peridotites, perhaps in many cases as through-going melt flow zones, and left pockets of trapped melt.

Trace-element data, nonetheless, contain evidence for the presence of a background matrix of depleted peridotite with compositions little modified since melt extraction (Fig. 7A), and which are distributed evenly throughout the drill holes (Fig. 8).These samples are those with chondrite-normalized REE patterns that can be modeled in terms of $15 \%$ to $20 \%$ fractional melting of spinel peridotite.

Peridotite with comparatively LREE-enriched bulk compositions is also present. The most enriched samples are localized at a depth of about 100 meters below seafloor in both Holes 920B and 920D (Fig. 
Table 4. Average clinopyroxene compositions for peridotites from Site 920.

\begin{tabular}{|c|c|c|c|c|c|c|c|c|c|c|c|c|c|c|c|c|}
\hline Hole: & $153-920 \mathrm{~B}$ & 153-920B & $153-920 \mathrm{~B}$ & $153-920 \mathrm{~B}$ & 153-920B & 153-920B & $153-920 \mathrm{~B}$ & 153-920B & 153-920B & 153-920D & 153-920D & 153-920D & 153-920D & 153-920D & 153-920D & 153-920D \\
\hline Core, section: & 13R-1 & $12 \mathrm{R}-5$ & $12 R-4$ & $13 \mathrm{R}-2$ & $2 \mathrm{R}-1$ & $1 \mathrm{~W}-3$ & $10 \mathrm{R}-1$ & $12 \mathrm{R}-5$ & $13 R-2$ & $14 \mathrm{R}-3$ & $7 \mathrm{R}-2$ & $12 \mathrm{R}-1$ & $12 \mathrm{R}-3$ & $6 \mathrm{R}-3$ & $12 \mathrm{R}-3$ & $5 R-2$ \\
\hline Interval $(\mathrm{cm})$ : & $66-72$ & $18-23$ & $84-90$ & $114-120$ & $20-26$ & $70-73$ & $102-108$ & $23-28$ & $107-114$ & $7-12$ & $71-78$ & 73-78 & $29-35$ & $63-68$ & $35-39$ & $76-82$ \\
\hline$n:$ & 14 & 10 & 11 & 7 & 1 & 9 & 5 & 12 & 15 & 15 & 11 & 7 & 6 & 16 & 8 & 1 \\
\hline $\mathrm{SiO}_{2}$ & 51.84 & 52.28 & 51.25 & 51.52 & 53.14 & 51.75 & 51.94 & 52.04 & 51.83 & 51.82 & 52.21 & 52.33 & 52.31 & 52.26 & 52.08 & 50.72 \\
\hline $\mathrm{TiO}_{2}$ & 0.10 & 0.09 & 0.10 & 0.11 & 0.10 & 0.12 & 0.10 & 0.10 & 0.10 & 0.09 & 0.11 & 0.12 & 0.12 & 0.12 & 0.13 & 0.15 \\
\hline $\mathrm{Al}_{2}^{2} \mathrm{O}_{3}$ & 4.69 & 4.41 & 4.87 & 4.72 & 3.72 & 4.84 & 4.82 & 4.91 & 4.43 & 4.83 & 4.50 & 4.73 & 3.97 & 4.63 & 4.60 & 5.35 \\
\hline $\mathrm{Cr}_{2} \mathrm{O}_{3}$ & 1.08 & 0.99 & 1.18 & 1.12 & 1.01 & 1.21 & 1.21 & 1.15 & 1.01 & $\begin{array}{l}1.16 \\
1.16\end{array}$ & 1.08 & 1.26 & 0.96 & 1.16 & 1.17 & 1.40 \\
\hline $\mathrm{FeO}$ & 2.44 & 2.48 & 2.39 & 2.45 & 2.21 & 2.31 & 2.65 & 2.45 & 2.55 & 2.73 & 2.32 & 2.17 & 2.22 & 2.22 & 2.17 & 2.25 \\
\hline $\mathrm{MnO}$ & 0.09 & 0.08 & 0.08 & 0.09 & 0.13 & 0.08 & 0.08 & 0.09 & 0.10 & 0.08 & 0.09 & 0.08 & 0.08 & 0.08 & 0.09 & 0.09 \\
\hline $\mathrm{NiO}$ & 0.06 & 0.03 & 0.05 & 0.04 & 0.05 & 0.06 & 0.05 & 0.06 & 0.05 & 0.06 & 0.05 & 0.05 & 0.06 & 0.05 & 0.07 & 0.05 \\
\hline $\mathrm{MgO}$ & 16.71 & 17.03 & 15.91 & 16.49 & 17.04 & 16.22 & 17.21 & 16.48 & 16.97 & 16.94 & 16.75 & 16.43 & 16.59 & 16.63 & 16.51 & 15.97 \\
\hline $\mathrm{CaO}$ & 23.14 & 22.89 & 23.36 & 22.80 & 23.96 & 23.51 & 22.34 & 23.26 & 22.59 & 22.47 & 23.33 & 23.53 & 23.51 & 23.41 & 23.41 & 23.27 \\
\hline $\mathrm{Na}_{2} \mathrm{O}$ & 0.06 & 0.07 & 0.06 & 0.09 & 0.04 & 0.07 & 0.08 & 0.07 & 0.07 & 0.10 & 0.07 & 0.13 & 0.10 & 0.09 & 0.10 & 0.03 \\
\hline $\mathrm{K}_{2} \mathrm{O}$ & 0.00 & 0.01 & 0.01 & 0.00 & 0.00 & 0.00 & 0.00 & 0.01 & 0.00 & 0.00 & 0.00 & 0.01 & 0.00 & 0.00 & 0.00 & 0.00 \\
\hline $\mathrm{Si}$ & 1.881 & 1.892 & 1.880 & 1.884 & 1.906 & 1.880 & 1.877 & 1.881 & 1.888 & 1.878 & 1.888 & 1.886 & 1.903 & 1.887 & 1.887 & 1.861 \\
\hline $\mathrm{Ti}$ & 0.003 & 0.003 & 0.003 & 0.003 & 0.003 & 0.003 & 0.003 & 0.003 & 0.003 & 0.002 & $\begin{array}{l}.0000 \\
0.003\end{array}$ & 0.003 & 0.004 & $\begin{array}{l}1.001 \\
0.003\end{array}$ & 0.003 & 0.004 \\
\hline $\mathrm{Al}$ & 0.200 & 0.188 & 0.210 & 0.203 & 0.157 & 0.207 & 0.205 & 0.209 & 0.190 & 0.206 & 0.192 & 0.201 & 0.1 & 0.14 & 0.197 & 0.231 \\
\hline $\mathrm{Cr}$ & 0.031 & 0.028 & 0.034 & 0.033 & 0.030 & 0.037 & 0.034 & 0.033 & 0.030 & 0.033 & 0.031 & 0.037 & 0.030 & 0.034 & 0.031 & 0.040 \\
\hline $\mathrm{Fe}^{2+}$ & 0.074 & 0.075 & 0.073 & 0.075 & 0.066 & 0.070 & 0.080 & 0.074 & 0.078 & 0.083 & 0.070 & 0.066 & 0.068 & 0.067 & 0.066 & 0.069 \\
\hline $\mathrm{Mn}$ & 0.003 & 0.002 & 0.003 & 0.002 & 0.004 & 0.002 & 0.003 & 0.003 & 0.003 & 0.003 & 0.003 & 0.002 & 0.003 & 0.0 & 0.003 & 0.003 \\
\hline $\mathrm{Ni}$ & 0.00 & 0.001 & 0.001 & 0.001 & 0.001 & 0.00 & 0.0 & 0.0 & 0.0 & 0.0 & 0.0 & 0.0 & 0.0 & 0.0 & 0.002 & 0.001 \\
\hline $\mathrm{Mg}$ & 0.9 & 0.919 & 0.870 & 0.898 & 0.911 & 0.87 & 0.9 & 0.8 & 0.9 & 0.9 & 0.9 & 0.8 & 0.9 & 0.8 & 0.8 & 0.873 \\
\hline $\mathrm{Ca}$ & & 0.887 & 0.9 & 0.893 & 0.92 & 0.91 & 0.8 & 0.9 & 0.88 & 0.873 & 0.9 & 0.909 & 0.9 & 0.9 & 0.909 & 0.915 \\
\hline $\mathrm{Na}$ & & 0.005 & 0.005 & 0.006 & 0.003 & 0.005 & 0.006 & 0.005 & 0.005 & 0.007 & 0.005 & 0.009 & 0.007 & 0.006 & 0.007 & 0.002 \\
\hline $\mathrm{K}$ & 0.000 & 0.000 & 0.000 & 0.000 & 0.000 & 0.000 & 0.000 & 0.000 & 0.000 & 0.000 & 0.000 & 0.000 & 0.000 & 0.000 & 0.000 & 0.000 \\
\hline Mg\# & 92.45 & 92.43 & 92.23 & 92.31 & 93.24 & 92.61 & 92.06 & 92.31 & 92.22 & 91.70 & 92.77 & 93.09 & 93.02 & 93.04 & 93.15 & 92.68 \\
\hline $\mathrm{Cr} \#$ & 13.56 & 12.97 & 13.78 & 13.92 & 16.04 & 15.05 & $\begin{array}{l}14.23 \\
\end{array}$ & 13.45 & 13.62 & 13.6 & 13.8 & 15. & 15. & 14. & $\begin{array}{l}13.72 \\
\end{array}$ & $\begin{array}{l}14.76\end{array}$ \\
\hline Wo & $\begin{array}{l}47.93 \\
\end{array}$ & 47.17 & $\begin{array}{l}49.33 \\
\end{array}$ & 47.85 & 48.52 & $\begin{array}{l}49.10 \\
\end{array}$ & 46.22 & $\begin{array}{l}1.43 \\
48.36\end{array}$ & $\begin{array}{r}1.02 \\
46.89\end{array}$ & $\begin{array}{l}1.09 \\
46.66\end{array}$ & $\begin{array}{l}18.89 \\
48.16\end{array}$ & $\begin{array}{l}4.02 \\
48.93\end{array}$ & $\begin{array}{l} \\
48.64\end{array}$ & $\begin{array}{l}4.07 \\
48.50\end{array}$ & 48.68 & 49.27 \\
\hline En & 48.14 & 48.83 & 46.73 & 48.14 & 48.00 & 47.14 & 49.51 & 47.67 & 48.98 & 48.91 & 48.09 & 47.53 & 47.77 & 47.91 & 47.80 & 47.01 \\
\hline $\mathrm{Fs}$ & 3.93 & 4.00 & 3.94 & 4.01 & 3.48 & 3.76 & 4.27 & 3.97 & 4.13 & 4.43 & 3.75 & 3.53 & 3.58 & 3.58 & 3.52 & 3.72 \\
\hline
\end{tabular}

Notes: Averages are for all analyses from each sample filtered for $\mathrm{CaO}>19.5 \%$. Data are in weight percent (wt $\%) ; n=$ number of analyses; molecular formula was calculated for $\mathrm{O}=6$. Wo $=$ wollastonite content, En $=$ enstatite content, Fs $=$ ferrosilite content. 
Table 4 (continued).

\begin{tabular}{|c|c|c|c|c|c|c|c|c|c|c|c|c|c|c|c|c|}
\hline Hole: & 153-920D & 153-920D & 153-920D & 153-920D & 153-920D & 153-920D & 153-920D & 153-920D & 153-920D & 153-920D & 153-920D & 153-920D & 153-920D & 153-920D & 153-920D & Average \\
\hline Core, section: & $5 \mathrm{R}-2$ & $2 \mathrm{R}-2$ & $14 \mathrm{R}-4$ & $15 \mathrm{R}-1$ & $16 \mathrm{R}-3$ & $22 \mathrm{R}-5$ & $22 \mathrm{R}-3$ & $18 \mathrm{R}-2$ & $15 \mathrm{R}-3$ & 20R-5 & $15 \mathrm{R}-3$ & $22 \mathrm{R}-2$ & $18 \mathrm{R}-4$ & $15 \mathrm{R}-5$ & $22 \mathrm{R}-5$ & \\
\hline Interval $(\mathrm{cm})$ : & $76-82$ & $33-38$ & $76-82$ & $8-15$ & $64-70$ & $11-116$ & $19-23$ & $35-41$ & $36-40$ & $54-60$ & $114-119$ & $69-73$ & $86-93$ & $14-22$ & $3-9$ & \\
\hline$n:$ & 1 & 2 & 16 & 13 & 27 & 18 & 9 & 12 & 12 & 27 & 17 & 14 & 3 & 17 & 21 & 365 \\
\hline $\mathrm{SiO}_{2}$ & 50.72 & 52.17 & 52.01 & 51.67 & 51.87 & 51.74 & 51.85 & 51.40 & 51.95 & 51.71 & 51.86 & 50.74 & 51.59 & 51.85 & 50.92 & 51.77 \\
\hline $\mathrm{TiO}_{2}$ & 0.15 & 0.13 & 0.10 & 0.09 & 0.10 & 0.12 & 0.11 & 0.17 & 0.10 & 0.10 & 0.12 & $\begin{array}{r}0.14 \\
0.12\end{array}$ & 0.12 & 0.11 & 0.11 & 0.11 \\
\hline 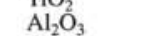 & 5.35 & 4.90 & 4.77 & 4.69 & 4.89 & 4.59 & 4.67 & 5.24 & 4.93 & 4.47 & 4.69 & 5.25 & 5.02 & 4.50 & 4.89 & 4.72 \\
\hline $\begin{array}{l}\mathrm{A}_{2} \mathrm{C}_{2} \mathrm{O}_{3} \\
\mathrm{Cr}_{2} \mathrm{O}_{3}\end{array}$ & 1.40 & $\begin{array}{l}1.29 \\
1.29\end{array}$ & 1.08 & $\begin{array}{l}4.09 \\
1.13\end{array}$ & $\begin{array}{l}4.89 \\
1.16\end{array}$ & 1.11 & $\begin{array}{l}4.01 \\
1.06\end{array}$ & 1.28 & 1.15 & $\begin{array}{l}4.47 \\
1.02\end{array}$ & 1.11 & 1.28 & 1.28 & 0.99 & $\begin{array}{l}4.87 \\
1.19\end{array}$ & 1.12 \\
\hline $\mathrm{FeO}$ & 2.25 & 2.12 & 2.65 & 2.75 & $\begin{array}{l}1.10 \\
2.73\end{array}$ & $\begin{array}{l}1.11 \\
2.59\end{array}$ & 2.64 & $\begin{array}{l}1.28 \\
2.38\end{array}$ & 2.84 & 2.33 & $\begin{array}{l}1.11 \\
2.78\end{array}$ & $\begin{array}{l}1.28 \\
2.56\end{array}$ & $\begin{array}{l}1.28 \\
2.39\end{array}$ & 2.59 & $\begin{array}{l}1.19 \\
2.58\end{array}$ & $\begin{array}{l}1.12 \\
2.52\end{array}$ \\
\hline $\mathrm{MnO}$ & 0.09 & 0.10 & 0.09 & 0.10 & 0.10 & 0.10 & 0.10 & 0.07 & 0.09 & 0.07 & 0.10 & 0.10 & 0.08 & 0.09 & 0.08 & 0.09 \\
\hline $\mathrm{NiO}$ & 0.05 & 0.05 & 0.06 & 0.04 & 0.04 & 0.06 & 0.04 & 0.06 & 0.06 & 0.05 & 0.05 & 0.06 & 0.05 & 0.04 & 0.05 & 0.05 \\
\hline $\mathrm{MgO}$ & 15.97 & 16.30 & 17.05 & 17.02 & 17.34 & 16.64 & 16.94 & 16.06 & 17.58 & 16.78 & 17.05 & 16.28 & 16.54 & 17.15 & 16.21 & 16.75 \\
\hline $\mathrm{CaO}$ & 23.27 & 23.85 & 22.66 & 22.48 & 22.31 & 22.72 & 22.25 & 23.59 & 21.31 & 23.08 & 22.45 & 22.67 & 23.72 & 22.46 & 23.50 & 22.87 \\
\hline $\mathrm{Na}_{2} \mathrm{O}$ & 0.03 & 0.10 & 0.07 & 0.08 & 0.10 & 0.08 & 0.11 & 0.11 & 0.08 & 0.08 & 0.11 & 0.11 & 0.21 & 0.08 & 0.11 & 0.09 \\
\hline $\mathrm{K}_{2} \mathrm{O}$ & 0.00 & 0.02 & 0.00 & 0.01 & 0.01 & 0.01 & 0.01 & 0.01 & 0.01 & 0.00 & 0.01 & 0.01 & 0.00 & 0.00 & 0.01 & 0.01 \\
\hline $\mathrm{Si}$ & 1.861 & 1.879 & 1.880 & 1.878 & 1.873 & 1.886 & 1.887 & 1.866 & 1.881 & 1.886 & 1.880 & 1.863 & 1.863 & 1.886 & 1.865 & 1.880 \\
\hline $\mathrm{Ti}$ & 0.004 & 0.004 & 0.003 & 0.002 & 0.003 & 0.003 & 0.003 & 0.005 & 0.003 & 0.003 & 0.003 & 0.003 & 0.003 & 0.003 & 0.003 & 0.003 \\
\hline $\mathrm{Al}$ & 0.231 & 0.208 & 0.203 & 0.201 & 0.208 & 0.197 & 0.200 & 0.224 & 0.210 & 0.192 & 0.200 & 0.227 & 0.213 & 0.193 & 0.211 & 0.202 \\
\hline $\mathrm{Cr}$ & 0.040 & 0.040 & 0.031 & 0.032 & 0.032 & 0.032 & 0.030 & 0.036 & 0.032 & 0.031 & 0.030 & 0.038 & 0.037 & 0.029 & 0.035 & 0.032 \\
\hline $\mathrm{Fe}^{2+}$ & 0.069 & 0.064 & 0.080 & 0.084 & 0.082 & 0.079 & 0.080 & $\begin{array}{l}0.030 \\
0.072\end{array}$ & 0.086 & 0.071 & 0.084 & $\begin{array}{l}0.038 \\
0.079\end{array}$ & $\begin{array}{l}0.071 \\
0.072\end{array}$ & $\begin{array}{l}0.029 \\
0.079\end{array}$ & 0.079 & 0.077 \\
\hline $\mathrm{Mn}$ & 0.003 & 0.003 & 0.003 & 0.003 & 0.003 & 0.003 & 0.003 & 0.002 & 0.003 & 0.002 & 0.003 & 0.003 & 0.002 & 0.003 & 0.002 & 0.003 \\
\hline $\mathrm{Ni}$ & 0.001 & 0.002 & 0.002 & 0.001 & 0.001 & 0.002 & 0.001 & 0.002 & 0.002 & 0.001 & 0.001 & 0.002 & 0.001 & 0.001 & 0.002 & 0.001 \\
\hline $\mathrm{Mg}$ & 0.873 & 0.875 & 0.919 & 0.922 & 0.933 & 0.904 & 0.918 & 0.869 & 0.948 & 0.912 & 0.921 & 0.891 & 0.890 & 0.930 & 0.885 & 0.907 \\
\hline $\mathrm{Ca}$ & 0.915 & 0.920 & 0.878 & 0.876 & 0.863 & 0.887 & 0.868 & 0.918 & 0.827 & 0.902 & 0.872 & 0.892 & 0.918 & 0.875 & 0.923 & 0.890 \\
\hline $\mathrm{Na}$ & 0.002 & 0.007 & 0.005 & 0.006 & 0.007 & 0.006 & 0.008 & 0.007 & 0.006 & 0.006 & 0.008 & 0.008 & & 0.006 & 0.008 & 0.006 \\
\hline K & 0.000 & 0.001 & 0.000 & 0.000 & 0.000 & 0.000 & 0.000 & 0.000 & 0.000 & 0.000 & 0.000 & 0.000 & 0.000 & 0.000 & 0.000 & 0.000 \\
\hline $\mathrm{Mg} \#$ & 92.68 & 93.18 & 91.98 & 91.69 & 91.89 & 91.98 & 91.96 & 92.33 & 91.69 & 92.76 & 91.63 & 91.90 & 92.52 & 92.18 & 91.81 & 92.22 \\
\hline Cr\# & 14.76 & 16.13 & 13.11 & 13.87 & 13.41 & 14.06 & 13.04 & 13.79 & 13.11 & 13.81 & $\begin{array}{l}13.03 \\
\end{array}$ & 14.30 & 14.67 & 13.24 & 14.31 & 13.80 \\
\hline Wo & 49.27 & 49.49 & $\begin{array}{l}46.77 \\
\end{array}$ & 46.54 & 45.95 & 47.43 & $\begin{array}{l}46.49 \\
\end{array}$ & 49.36 & 44.42 & 47.84 & $\begin{array}{l}46.03 \\
\end{array}$ & 47.91 & 48.82 & $\begin{array}{l}46.47 \\
\end{array}$ & 48.90 & 47.51 \\
\hline En & 47.01 & 47.07 & 48.96 & 49.01 & $\begin{array}{l}49.67 \\
\end{array}$ & 48.35 & 49.21 & 46.76 & 50.96 & 48.38 & 49.07 & 47.86 & 47.35 & 49.35 & 46.91 & 48.40 \\
\hline $\mathrm{Fs}$ & 3.72 & 3.44 & 4.27 & 4.44 & 4.38 & 4.22 & 4.30 & 3.88 & 4.62 & 3.77 & 4.48 & 4.22 & 3.83 & 4.19 & 4.19 & 4.08 \\
\hline
\end{tabular}


$8)$, at the level where granular dunite zones were recovered. Wholerock chemical data suggest that these are cumulate dunites for which the bulk rock $\mathrm{Mg} \#$ is slightly less (about 90) than that measured for $\mathrm{Mg} \#$ of olivine in peridotite (average 90.7). These data suggest that the dunites are residual after the localized passage of a melt that crystallized olivine in the manner suggested by Takazawa et al. (1992).

Onboard discussion (Shipboard Scientific Party, 1995) noted the occurrence of black, sheared, pyroxene-poor harzburgite to dunite in the vicinity of gabbro and pyroxenite (sensu lato) veins (see, for example, Casey, this volume; Niida, this volume), and centered around whether the dunites and highly depleted harzburgites were residual after the removal of pyroxene by melting in close association with the observed veins, or early-formed olivine-rich zones that had localized deformation and fluid migration resulting from their relative ductility under shear stress.

Impregnation marginal to individual veinlets, however, is shown to be restricted to enrichments in mineral chemistry on a centimeter scale (Niida, this volume). Samples investigated in this study were selected in intervals of good core recovery, however, such that the likelihood of nearby veins, which were not recovered by drilling, contributing to the enrichment was minimized. The homogeneous mineral chemistry of peridotite phases argues against melt being sweated from, or interacting with, the adjacent wall rocks on a broad scale. Melt passage that left its signature in the presence of the granular dunite zone was most probably related to a broader metasomatic event that has left a more pervasive signature on the surrounding peridotite.

\section{ACKNOWLEDGMENTS}

Access to analytical facilities and funding for analyses was supported partly by Professor K.D. Collerson, Head, The Department of Earth Sciences, The University of Queensland. Y. Niu assisted with ICP-MS analyses and freely discussed the concept of excess olivine. These discussions significantly advanced this paper, as did reviews by R. Hebert and D. Elthon.

\section{REFERENCES}

Bodinier, J.L., Vasseur, G., Vernieres, J., Dupuy, C., and Fabries, J., 1990. Mechanisms of mantle metasomatism: geochemical evidence from the Lherz Orogenic Peridotite. J. Petrol., 31:597-628.

Cannat, M., Bideau, D., and Hebert, R., 1990. Plastic deformation and magmatic impregnation in serpentinized ultramafic rocks from the Garrett transform fault (East Pacific Rise). Earth Planet. Sci. Lett., 101:216-232.

Cannat, M., and Casey, J.F., 1995. An ultramafic lift at the Mid-Atlantic Ridge: successive stages of magmatism in serpentinized peridotites from the $15^{\circ} \mathrm{N}$ region. In Vissers, R.L.M., and Nicolas, A. (Eds.), Mantle and Lower Crust Exposed in Oceanic Ridges and Ophiolites: Dordrecht (Kluwer), 5-34.

Ceuleneer, G., and Rabinowicz, M. 1993. Mantle flow and melt migration beneath oceanic ridges: models derived from observations in ophiolites. In Phipps Morgan, J., Blackman, D.K. and Sinton, J.M. (Eds.) Mantle Flow and Melt Generation at Mid-Ocean Ridges. Am. Geophys. Union, Geophysical Monograph 71: 123-154.

Dick, H.J.B., 1989. Abyssal peridotites, very slow spreading ridges and ocean ridge magmatism. In Saunders, A.D., and Norry, M.J. (Eds.), Magmatism in the Ocean Basins. Geol. Soc. Spec. Publ. London, 42:71-105.

Dick, H.J.B., Fisher, R.L., and Bryan, W.B., 1984. Mineralogic variability of the uppermost mantle along mid-ocean ridges. Earth Planet. Sci. Lett., 69:88-106.

Dostal, J., and Muecke, G.K., 1977. Trace element geochemistry of igneous rocks from Site 334, Leg 37. In Aumento, F., and Melson, W.G., et al., Init. Repts. DSDP, 37: Washington (U.S. Govt. Printing Office), 573576.

Elthon, D., 1992. Chemical trends in abyssal peridotites: refertilization of depleted suboceanic mantle. J. Geophys. Res., 97:9015-9025.
Ewart, A., and Hawkesworth, C.J., 1987. The Pleistocene-Recent TongaKermadec arc lavas: interpretation of new isotope and rare earth data in terms of a depleted mantle source model. J. Petrol., 28:495-530.

Forsyth, D.W., 1993. Geophysical constraints on mantle flow and melt generation beneath mid-ocean ridges. In Phipps Morgan, J., Blackman, D.K., and Sinton, J.M. (Eds.), Mantle Flow and Melt Generation at Mid-Ocean Ridges. Geophys. Monogr., Am. Geophys. Union, 71:1-66.

Gruau, G., Bernard-Griffiths, J., Lecuyer, C., Henin, O., Mace, J., and Cannat, M., 1995. Extreme Nd isotopic variation in the Trinity Ophiolite Complex and the role of melt/rock reactions in the oceanic lithosphere. Contrib. Mineral. Petrol., 121:337-350.

Gruau, G., Lecuyer, C., Bernard-Griffiths, J., and Morin, J., 1991. Origin and petrogenesis of the Trinity Ophiolite Complex (California): new constraints from REE and Nd isotope data. In Menzies, M.A., Dupuy, C., and Nicholas, A. (Eds.), Orogenic Lherzolites and Mantle Processes. J. Petrol. Spec. Issue, 229-242.

Hekinian, R., Thompson, G., and Bideau, D., 1989. Axial and off-axis heterogeneity of basaltic rocks from the East Pacific Rise at $12^{\circ} 35^{\prime} \mathrm{N}-12^{\circ} 51^{\prime} \mathrm{N}$ and $11^{\circ} 26^{\prime} \mathrm{N}-11^{\circ} 30^{\prime} \mathrm{N}$. J. Geophys. Res., 94:17437-17463.

Hess, P.C., 1993. Phase equilibria constraints on the origin of ocean floor basalts. In Phipps Morgan, J., Blackman, D.K., and Sinton, J.M. (Eds.), Mantle Flow and Melt Generation at Mid-Ocean Ridges. Geophys. Monogr., Am. Geophys. Union, 71:67-102.

Jacobsen, S.B., Quick, J.E., and Wasserburg, G.J., 1984. A Nd and Sr isotopic study of the Trinity peridotite: implications for mantle evolution. Earth Planet. Sci. Lett., 50:139-155.

Jacques, A.L., and Green, D.H., 1980. Anhydrous melting of peridotite at 0$15 \mathrm{~kb}$ pressure and the genesis of tholeiitic basalts. Contrib. Mineral. Petrol., 73:287-310.

Jagoutz, E., Palme, H., Baddenhausen, H., Blum, K., Cendales, M., Dreibus, G., Spettel, B., Lorenz, V., and Waenke, H., 1979. The abundances of major, minor and trace elements in the Earth's mantle as derived from primitive ultramafic nodules. Proc. 10th Lunar Planet. Sci. Conf., 20312050.

Johnson, K.T.M., Dick, H.J.B., and Shimizu, N., 1990. Melting in the oceanic upper mantle: an ion microprobe study of diopsides in abyssal peridotites. J. Geophys. Res., 95:2661-2678.

Juteau, T., Berger, E., and Cannat, M., 1990. Serpentinized, residual mantle peridotites from the M.A.R. median valley, ODP Hole $670 \mathrm{~A}\left(21^{\circ} 10^{\prime} \mathrm{N}\right.$, $45^{\circ} 02^{\prime} \mathrm{W}$, Leg 109): primary mineralogy and geothermometry. In Detrick, R., Honnorez, J., Bryan, W.B., Juteau, T., et al., Proc. ODP, Sci. Results, 106/109: College Station, TX (Ocean Drilling Program), 27-45.

Klein, E.M., and Langmuir, C.H., 1987. Global correlations of ocean ridge basalt chemistry with axial depth and crustal thickness. J. Geophys. Res., 92:8089-8115.

Langmuir, C.H., Klein, E.M., and Plank, T. 1993. Petrological systematics of mid-ocean ridge basalts: Constraints on melt generation beneath midocean ridges. In Phipps Morgan, J., Blackman, D.K., and Sinton, J.M. (Eds.), Mantle Flow and Melt Generation at Mid-Ocean Ridges. Am. Geophys. Union, Geophysical Monograph 71: 183-280.

McKenzie, D., and Bickle, M.J., 1988. The volume and composition of melt generated by extension of the lithosphere. J. Petrol., 29:625-679.

Michael, P.J., and Bonatti, E., 1985. Peridotite composition from the North Atlantic: regional and tectonic variations and implications for partial melting. Earth Planet. Sci. Lett., 73:91-104.

Mysen, B.O., and Kushiro, I., 1977. Compositional variations of coexisting phases with degree of melting of peridotite in the upper mantle. Am. Mineral., 62:843-865.

Navon, O., and Stolper, E., 1987. Geochemical consequences of melt percolation: the upper mantle as a chromatographic column. J. Geol., 95:285307.

Niu, Y., and Batiza, R., 1993. Melting processes under fast and slow midocean ridges. IAVCEI General Assembly, September 1993, Canberra, Australia, 8. (Abstract)

Niu, Y., Langmuir, C.H., and Kinzler, R.J., 1995. Oceanic peridotite genesis and mantle melting beneath slow-spreading ridges. Terra Nova, 7:144.

Pallister, J.S., and Knight, R.J., 1981. Rare-earth element geochemistry of the Samail ophiolite near Ibra, Oman. J. Geophys. Res., 86:2673-2697.

Parsons, B., and Sclater, J.G., 1977. An analysis of the variation of ocean floor bathymetry and heat flow with age. J. Geophys. Res., 82:803-827.

Prinzhofer, A., and Allègre, C.J., 1985. Residual peridotites and the mechanisms of partial melting. Earth Planet. Sci. Lett., 74:251-265. 
Quick, J.E., 1981. Petrology and petrogenesis of the Trinity Peridotite, an upper mantle diapir in the eastern Klamath Mountains, northern California. J. Geophys. Res., 86:11837-11863.

Ross, K., and Elthon, D., 1993. Cumulates from strongly depleted midocean-ridge basalt. Nature, 365:826-829.

Shibata, T., and Thompson, G., 1986. Peridotites from the Mid-Atlantic Ridge at $43^{\circ} \mathrm{N}$ and their petrogenetic relation to abyssal tholeiites. Contrib. Mineral. Petrol., 93:144-159.

Shipboard Scientific Party, 1995. Site 920. In Cannat, M., Karson, J.A. Miller, D.J., et al., Proc. ODP, Init. Repts., 153: College Station, TX (Ocean Drilling Program), 45-119.

Sun, S.-S., and McDonough, W.F., 1989. Chemical and isotopic systematics of oceanic basalts: implications for mantle compositions and processes.
In Saunders, A.D., and Norry, M.J. (Eds.), Magmatism in the Ocean Basins. Geol. Soc. Spec. Publ. London, 42:313-345.

Takahashi, N., 1992. Evidence for melt segregation toward fractures in the Horoman mantle peridotite complex. Nature, 359:52-55.

Takazawa, E., Frey, F.A., Shimizu, N., Obata, M., and Bodinier, J.L., 1992. Geochemical evidence for melt migration and reaction in the upper mantle. Nature, 359:55-58.

Date of initial receipt: 21 August 1995

Date of acceptance: 1 May 1996

Ms 153SR-016 
Table 5. Average orthopyroxene compositions for peridotites from Site 920.

\begin{tabular}{|c|c|c|c|c|c|c|c|c|c|c|c|c|c|c|c|c|c|}
\hline Hole: & $153-920 \mathrm{~B}$ & 153-920B & 153-920B & 153-920B & 153-920B & 153-920B & 153-920B & 153-920B & 153-920B & 153-920B & 153-920B & 153-920D & $153-920 \mathrm{D}$ & 153-920D & 153-920D & 153-920D & 153-920D \\
\hline Core, section: & $13 \mathrm{R}-1$ & $12 \mathrm{R}-5$ & $12 R-4$ & $13 \mathrm{R}-2$ & $2 \mathrm{R}-1$ & $3 \mathrm{R}-2$ & $4 R-1$ & IW-3 & $10 \mathrm{R}-1$ & $12 \mathrm{R}-5$ & $13 \mathrm{R}-2$ & $14 \mathrm{R}-3$ & $7 \mathrm{R}-2$ & $12 \mathrm{R}-\mathrm{I}$ & $12 \mathrm{R}-3$ & $6 \mathrm{R}-3$ & $12 \mathrm{R}-3$ \\
\hline Interval $(\mathrm{cm})$ : & $66-72$ & $18-23$ & $84-90$ & $114-120$ & $20-26$ & $82-89$ & $129-136$ & $70-73$ & $102-108$ & $23-28$ & $107-114$ & $7-12$ & 71-78 & 73-78 & $29-35$ & 63-68 & $35-39$ \\
\hline$n:$ & 3 & 4 & 2 & 8 & 4 & 6 & 7 & 8 & 6 & 5 & 4 & 15 & 9 & 7 & 4 & 8 & 6 \\
\hline $\begin{array}{l}\mathrm{SiO}_{2} \\
\mathrm{TiO}_{2} \\
\mathrm{Al}_{2} \mathrm{O}_{3} \\
\mathrm{Cr}_{2} \mathrm{O}_{3} \\
\mathrm{FeO} \\
\mathrm{MnO} \\
\mathrm{NiO} \\
\mathrm{MgO} \\
\mathrm{CaO} \\
\mathrm{Na}{ }_{2} \mathrm{O} \\
\mathrm{K}_{2} \mathrm{O}\end{array}$ & $\begin{array}{r}54.69 \\
0.04 \\
4.63 \\
0.99 \\
5.71 \\
0.12 \\
0.08 \\
32.48 \\
1.74 \\
0.01 \\
0.01\end{array}$ & $\begin{array}{r}55.14 \\
0.03 \\
4.19 \\
0.81 \\
5.95 \\
0.15 \\
0.10 \\
32.69 \\
1.23 \\
0.01 \\
0.01\end{array}$ & $\begin{array}{r}54.40 \\
0.06 \\
4.78 \\
1.03 \\
5.82 \\
0.14 \\
0.10 \\
31.48 \\
1.86 \\
0.00 \\
0.00\end{array}$ & $\begin{array}{r}55.14 \\
0.05 \\
3.91 \\
0.77 \\
5.91 \\
0.14 \\
0.09 \\
32.17 \\
1.32 \\
0.00 \\
0.00\end{array}$ & $\begin{array}{r}55.65 \\
0.03 \\
4.37 \\
0.87 \\
5.96 \\
0.14 \\
0.08 \\
33.03 \\
1.01 \\
0.01 \\
0.01\end{array}$ & $\begin{array}{r}54.62 \\
0.03 \\
4.23 \\
0.83 \\
5.98 \\
0.13 \\
0.11 \\
32.83 \\
1.55 \\
0.01 \\
0.01\end{array}$ & $\begin{array}{r}55.58 \\
0.05 \\
4.18 \\
0.85 \\
5.91 \\
0.13 \\
0.12 \\
32.98 \\
1.18 \\
0.02 \\
0.01\end{array}$ & $\begin{array}{r}55.45 \\
0.03 \\
3.79 \\
0.71 \\
5.92 \\
0.14 \\
0.09 \\
33.00 \\
1.50 \\
0.01 \\
0.01\end{array}$ & $\begin{array}{r}55.36 \\
0.05 \\
4.27 \\
0.91 \\
5.91 \\
0.13 \\
0.12 \\
32.52 \\
1.63 \\
0.02 \\
0.00\end{array}$ & $\begin{array}{r}54.96 \\
0.04 \\
4.74 \\
0.94 \\
5.97 \\
0.14 \\
0.11 \\
32.52 \\
1.41 \\
0.01 \\
0.01\end{array}$ & $\begin{array}{r}55.27 \\
0.02 \\
3.83 \\
0.73 \\
5.95 \\
0.15 \\
0.10 \\
32.53 \\
1.15 \\
0.01 \\
0.01\end{array}$ & $\begin{array}{r}55.44 \\
0.05 \\
3.87 \\
0.72 \\
6.12 \\
0.15 \\
0.08 \\
32.71 \\
1.42 \\
0.01 \\
0.01\end{array}$ & $\begin{array}{r}55.34 \\
0.04 \\
3.85 \\
0.77 \\
6.06 \\
0.13 \\
0.10 \\
33.13 \\
1.18 \\
0.01 \\
0.01\end{array}$ & $\begin{array}{r}55.75 \\
0.03 \\
4.13 \\
0.86 \\
6.03 \\
0.13 \\
0.10 \\
32.98 \\
1.22 \\
0.01 \\
0.01\end{array}$ & $\begin{array}{r}55.08 \\
0.04 \\
4.01 \\
0.81 \\
5.87 \\
0.14 \\
0.11 \\
32.21 \\
1.76 \\
0.01 \\
0.00\end{array}$ & $\begin{array}{r}55.45 \\
0.03 \\
4.20 \\
0.88 \\
6.00 \\
0.14 \\
0.10 \\
32.67 \\
1.56 \\
0.01 \\
0.01\end{array}$ & $\begin{array}{r}55.65 \\
0.06 \\
3.94 \\
0.78 \\
5.96 \\
0.13 \\
0.10 \\
33.04 \\
1.22 \\
0.00 \\
0.01\end{array}$ \\
\hline $\begin{array}{l}\mathrm{Si} \\
\mathrm{Ti} \\
\mathrm{Al} \\
\mathrm{Cr} \\
\mathrm{Fe} \\
\mathrm{Mn} \\
\mathrm{Ni} \\
\mathrm{Mg} \\
\mathrm{Ca} \\
\mathrm{Na} \\
\mathrm{K}\end{array}$ & $\begin{array}{l}1.885 \\
0.001 \\
0.188 \\
0.030 \\
0.165 \\
0.004 \\
0.002 \\
1.669 \\
0.064 \\
0.000 \\
0.000\end{array}$ & $\begin{array}{l}1.902 \\
0.001 \\
0.170 \\
0.020 \\
0.172 \\
0.004 \\
0.003 \\
1.681 \\
0.045 \\
0.001 \\
0.000\end{array}$ & $\begin{array}{l}1.892 \\
0.002 \\
0.196 \\
0.030 \\
0.169 \\
0.004 \\
0.003 \\
1.633 \\
0.069 \\
0.000 \\
0.000\end{array}$ & $\begin{array}{l}1.916 \\
0.001 \\
0.160 \\
0.020 \\
0.172 \\
0.004 \\
0.002 \\
1.666 \\
0.049 \\
0.000 \\
0.000\end{array}$ & $\begin{array}{l}1.902 \\
0.001 \\
0.176 \\
0.023 \\
0.171 \\
0.004 \\
0.002 \\
1.683 \\
0.037 \\
0.001 \\
0.000\end{array}$ & $\begin{array}{l}1.888 \\
0.001 \\
0.172 \\
0.022 \\
0.173 \\
0.004 \\
0.003 \\
1.692 \\
0.057 \\
0.001 \\
0.000\end{array}$ & $\begin{array}{l}1.903 \\
0.001 \\
0.169 \\
0.023 \\
0.169 \\
0.004 \\
0.003 \\
1.683 \\
0.043 \\
0.002 \\
0.000\end{array}$ & $\begin{array}{l}1.907 \\
0.001 \\
0.154 \\
0.020 \\
0.170 \\
0.004 \\
0.003 \\
1.692 \\
0.056 \\
0.001 \\
0.000\end{array}$ & $\begin{array}{l}1.900 \\
0.002 \\
0.173 \\
0.025 \\
0.170 \\
0.004 \\
0.003 \\
1.664 \\
0.060 \\
0.001 \\
0.000\end{array}$ & $\begin{array}{l}1.888 \\
0.001 \\
0.192 \\
0.024 \\
0.172 \\
0.004 \\
0.003 \\
1.665 \\
0.052 \\
0.001 \\
0.000\end{array}$ & $\begin{array}{l}1.915 \\
0.001 \\
0.157 \\
0.020 \\
0.173 \\
0.004 \\
0.003 \\
1.681 \\
0.043 \\
0.001 \\
0.000\end{array}$ & $\begin{array}{l}1.909 \\
0.001 \\
0.157 \\
0.021 \\
0.176 \\
0.004 \\
0.002 \\
1.679 \\
0.052 \\
0.001 \\
0.000\end{array}$ & $\begin{array}{l}1.904 \\
0.001 \\
0.156 \\
0.020 \\
0.174 \\
0.004 \\
0.003 \\
1.699 \\
0.043 \\
0.001 \\
0.000\end{array}$ & $\begin{array}{l}1.905 \\
0.001 \\
0.166 \\
0.023 \\
0.172 \\
0.003 \\
0.003 \\
1.680 \\
0.045 \\
0.001 \\
0.000\end{array}$ & $\begin{array}{l}1.907 \\
0.001 \\
0.163 \\
0.020 \\
0.170 \\
0.004 \\
0.003 \\
1.662 \\
0.065 \\
0.001 \\
0.000\end{array}$ & $\begin{array}{l}1.901 \\
0.001 \\
0.170 \\
0.021 \\
0.172 \\
0.004 \\
0.003 \\
1.670 \\
0.057 \\
0.001 \\
0.000\end{array}$ & $\begin{array}{l}1.908 \\
0.002 \\
0.159 \\
0.020 \\
0.171 \\
0.004 \\
0.003 \\
1.689 \\
0.045 \\
0.000 \\
0.000\end{array}$ \\
\hline
\end{tabular}

Notes: Averages for all analyses for each sample filtered for $\mathrm{CaO}<3 \%$. Data are in weight percent (wt\%); molecular formula was calculated for $\mathrm{O}=6$. Other abbreviations as in Table 4 . 
Table 5 (continued).

\begin{tabular}{|c|c|c|c|c|c|c|c|c|c|c|c|c|c|c|c|c|}
\hline Hole: & 153-920D & 153-920D & 153-920D & 153-920D & $153-920 \mathrm{D}$ & 153-920D & 153-920D & 153-920D & 153-920D & 153-920D & 153-920D & 153-920D & 153-920D & 153-920D & 153-920D & Average \\
\hline Core, section: & $5 R-2$ & $2 \mathrm{R}-2$ & $14 \mathrm{R}-4$ & $15 \mathrm{R}-1$ & $16 \mathrm{R}-3$ & $22 \mathrm{R}-5$ & $22 \mathrm{R}-3$ & $18 \mathrm{R}-2$ & $15 \mathrm{R}-3$ & 20R-5 & $15 \mathrm{R}-3$ & $22 \mathrm{R}-2$ & $18 \mathrm{R}-4$ & $15 R-5$ & $22 \mathrm{R}-5$ & \\
\hline Interval $(\mathrm{cm})$ : & $76-82$ & $33-38$ & $76-82$ & $8-15$ & $64-70$ & $11-116$ & $19-23$ & $35-41$ & $36-40$ & $54-60$ & $114-119$ & $69-73$ & $86-93$ & $14-22$ & $3-9$ & \\
\hline$n:$ & 7 & 4 & 17 & 19 & 17 & 9 & 10 & 14 & 4 & 14 & 13 & 12 & 2 & 17 & 8 & 282 \\
\hline $\begin{array}{l}\mathrm{SiO}_{2} \\
\mathrm{TO}_{2} \\
\mathrm{Al}_{2} \mathrm{O}_{3} \\
\mathrm{Cr}_{2} \mathrm{O}_{3} \\
\mathrm{FeO} \\
\mathrm{MnO} \\
\mathrm{NiO} \\
\mathrm{MgO} \\
\mathrm{CaO} \\
\mathrm{Na}_{2} \mathrm{O} \\
\mathrm{K}_{2} \mathrm{O}\end{array}$ & $\begin{array}{r}54.86 \\
0.03 \\
4.33 \\
0.88 \\
6.05 \\
0.14 \\
0.11 \\
32.78 \\
1.35 \\
0.01 \\
0.01\end{array}$ & $\begin{array}{r}55.78 \\
0.04 \\
3.98 \\
0.84 \\
6.04 \\
0.13 \\
0.08 \\
33.06 \\
1.28 \\
0.01 \\
0.00\end{array}$ & $\begin{array}{r}55.30 \\
0.04 \\
4.08 \\
0.79 \\
5.94 \\
0.14 \\
0.11 \\
32.98 \\
1.44 \\
0.02 \\
0.01\end{array}$ & $\begin{array}{r}54.92 \\
0.05 \\
4.29 \\
0.92 \\
6.04 \\
0.13 \\
0.12 \\
32.04 \\
1.77 \\
0.02 \\
0.01\end{array}$ & $\begin{array}{r}55.39 \\
0.04 \\
4.14 \\
0.84 \\
5.96 \\
0.14 \\
0.11 \\
33.07 \\
1.48 \\
0.02 \\
0.01\end{array}$ & $\begin{array}{r}55.20 \\
0.03 \\
4.08 \\
0.81 \\
5.94 \\
0.14 \\
0.10 \\
32.58 \\
1.43 \\
0.01 \\
0.01\end{array}$ & $\begin{array}{r}54.86 \\
0.04 \\
3.96 \\
0.78 \\
5.80 \\
0.13 \\
0.11 \\
32.35 \\
1.76 \\
0.03 \\
0.02\end{array}$ & $\begin{array}{r}54.63 \\
0.06 \\
4.96 \\
1.02 \\
6.02 \\
0.13 \\
0.10 \\
32.19 \\
1.51 \\
0.01 \\
0.00\end{array}$ & $\begin{array}{r}55.07 \\
0.03 \\
4.45 \\
0.93 \\
6.35 \\
0.14 \\
0.09 \\
32.47 \\
1.24 \\
0.01 \\
0.00\end{array}$ & $\begin{array}{r}54.63 \\
0.04 \\
4.09 \\
0.79 \\
5.82 \\
0.14 \\
0.09 \\
32.55 \\
1.62 \\
0.01 \\
0.00\end{array}$ & $\begin{array}{r}55.19 \\
0.06 \\
3.76 \\
0.73 \\
6.10 \\
0.15 \\
0.11 \\
32.65 \\
1.71 \\
0.02 \\
0.01\end{array}$ & $\begin{array}{r}54.94 \\
0.04 \\
3.87 \\
0.76 \\
5.83 \\
0.13 \\
0.09 \\
32.44 \\
1.52 \\
0.02 \\
0.01\end{array}$ & $\begin{array}{r}55.34 \\
0.04 \\
4.27 \\
0.88 \\
6.18 \\
0.11 \\
0.11 \\
33.46 \\
1.08 \\
0.01 \\
0.00\end{array}$ & $\begin{array}{r}55.13 \\
0.05 \\
3.88 \\
0.71 \\
5.88 \\
0.14 \\
0.09 \\
32.77 \\
1.62 \\
0.02 \\
0.00\end{array}$ & $\begin{array}{r}54.19 \\
0.03 \\
4.09 \\
0.79 \\
6.03 \\
0.15 \\
0.10 \\
32.37 \\
1.37 \\
0.02 \\
0.01\end{array}$ & $\begin{array}{r}55.13 \\
0.04 \\
4.11 \\
0.82 \\
5.96 \\
0.14 \\
0.10 \\
32.64 \\
1.48 \\
0.01 \\
0.01\end{array}$ \\
\hline $\begin{array}{l}\mathrm{Si} \\
\mathrm{Ti} \\
\mathrm{Al} \\
\mathrm{Cr} \\
\mathrm{Fe} \\
\mathrm{Mn} \\
\mathrm{Ni} \\
\mathrm{Mg} \\
\mathrm{Ca} \\
\mathrm{Na} \\
\mathrm{K}\end{array}$ & $\begin{array}{l}1.891 \\
0.001 \\
0.176 \\
0.024 \\
0.175 \\
0.004 \\
0.003 \\
1.684 \\
0.050 \\
0.001 \\
0.000\end{array}$ & $\begin{array}{l}1.907 \\
0.001 \\
0.160 \\
0.020 \\
0.172 \\
0.004 \\
0.002 \\
1.685 \\
0.047 \\
0.001 \\
0.000\end{array}$ & $\begin{array}{l}1.899 \\
0.001 \\
0.165 \\
0.020 \\
0.170 \\
0.004 \\
0.003 \\
1.688 \\
0.053 \\
0.002 \\
0.000\end{array}$ & $\begin{array}{l}1.899 \\
0.001 \\
0.175 \\
0.025 \\
0.175 \\
0.004 \\
0.003 \\
1.652 \\
0.066 \\
0.001 \\
0.000\end{array}$ & $\begin{array}{l}1.896 \\
0.001 \\
0.167 \\
0.022 \\
0.171 \\
0.004 \\
0.003 \\
1.688 \\
0.054 \\
0.001 \\
0.000\end{array}$ & $\begin{array}{l}1.904 \\
0.001 \\
0.166 \\
0.021 \\
0.171 \\
0.004 \\
0.003 \\
1.675 \\
0.053 \\
0.000 \\
0.000\end{array}$ & $\begin{array}{l}1.904 \\
0.001 \\
0.162 \\
0.020 \\
0.168 \\
0.004 \\
0.003 \\
1.674 \\
0.065 \\
0.002 \\
0.001\end{array}$ & $\begin{array}{l}1.882 \\
0.002 \\
0.201 \\
0.029 \\
0.173 \\
0.004 \\
0.003 \\
1.653 \\
0.056 \\
0.001 \\
0.000\end{array}$ & $\begin{array}{l}1.895 \\
0.001 \\
0.180 \\
0.023 \\
0.183 \\
0.004 \\
0.003 \\
1.665 \\
0.046 \\
0.000 \\
0.000\end{array}$ & $\begin{array}{l}1.897 \\
0.001 \\
0.167 \\
0.020 \\
0.169 \\
0.004 \\
0.003 \\
1.685 \\
0.060 \\
0.001 \\
0.000\end{array}$ & $\begin{array}{l}1.905 \\
0.002 \\
0.153 \\
0.020 \\
0.176 \\
0.004 \\
0.003 \\
1.680 \\
0.063 \\
0.001 \\
0.000\end{array}$ & $\begin{array}{l}1.908 \\
0.001 \\
0.158 \\
0.021 \\
0.169 \\
0.004 \\
0.003 \\
1.680 \\
0.057 \\
0.002 \\
0.000\end{array}$ & $\begin{array}{l}1.890 \\
0.001 \\
0.172 \\
0.020 \\
0.177 \\
0.003 \\
0.003 \\
1.703 \\
0.040 \\
0.001 \\
0.000\end{array}$ & $\begin{array}{l}1.904 \\
0.001 \\
0.158 \\
0.020 \\
0.170 \\
0.004 \\
0.002 \\
1.687 \\
0.060 \\
0.001 \\
0.000\end{array}$ & $\begin{array}{l}1.895 \\
0.001 \\
0.169 \\
0.023 \\
0.176 \\
0.005 \\
0.003 \\
1.688 \\
0.051 \\
0.001 \\
0.001\end{array}$ & $\begin{array}{l}1.901 \\
0.001 \\
0.167 \\
0.022 \\
0.172 \\
0.004 \\
0.003 \\
1.678 \\
0.055 \\
0.001 \\
0.000\end{array}$ \\
\hline $\begin{array}{l}\text { Mg\# } \\
\text { CrH } \\
\text { Wo } \\
\text { En } \\
\text { Fs }\end{array}$ & $\begin{array}{r}90.61 \\
12.13 \\
2.61 \\
88.24 \\
9.15\end{array}$ & $\begin{array}{r}90.72 \\
11.10 \\
2.47 \\
88.48 \\
9.05\end{array}$ & $\begin{array}{r}90.83 \\
10.81 \\
2.77 \\
88.31 \\
8.92\end{array}$ & $\begin{array}{r}90.44 \\
12.62 \\
3.48 \\
87.29 \\
9.23\end{array}$ & $\begin{array}{r}90.81 \\
11.53 \\
2.83 \\
88.24 \\
8.93\end{array}$ & $\begin{array}{r}90.72 \\
11.28 \\
2.79 \\
88.19 \\
9.02\end{array}$ & $\begin{array}{r}90.86 \\
10.99 \\
3.43 \\
87.74 \\
8.83\end{array}$ & $\begin{array}{r}90.51 \\
12.71 \\
2.96 \\
87.83 \\
9.21\end{array}$ & $\begin{array}{r}90.11 \\
11.10 \\
2.40 \\
87.95 \\
9.65\end{array}$ & $\begin{array}{r}90.89 \\
10.69 \\
3.15 \\
88.03 \\
8.82\end{array}$ & $\begin{array}{r}90.52 \\
11.56 \\
3.29 \\
87.54 \\
9.17\end{array}$ & $\begin{array}{r}90.84 \\
11.62 \\
2.97 \\
88.14 \\
8.89\end{array}$ & $\begin{array}{r}90.61 \\
10.42 \\
2.06 \\
88.74 \\
9.20\end{array}$ & $\begin{array}{r}90.86 \\
11.23 \\
3.12 \\
88.03 \\
8.86\end{array}$ & $\begin{array}{r}90.54 \\
11.78 \\
2.68 \\
88.12 \\
9.20\end{array}$ & $\begin{array}{r}90.70 \\
11.59 \\
2.88 \\
88.09 \\
9.03\end{array}$ \\
\hline
\end{tabular}


Table 6. Average chrome spinel compositions for peridotites from Site 920.

\begin{tabular}{|c|c|c|c|c|c|c|c|c|c|c|c|c|c|c|c|c|}
\hline Hole: & $153-920 \mathrm{~B}$ & 153-920B & 153-920B & 153-920B & 153-920B & 153-920B & 153-920B & $153-920 \mathrm{~B}$ & 153-920B & 153-920B & 153-920B & 153-920D & 153-920D & 153-920D & $153-920 \mathrm{D}$ & 153-920D \\
\hline Core, section: & 13R-1 & $12 \mathrm{R}-5$ & $12 \mathrm{R}-4$ & 13R-2 & 2R-1 & 3R-2 & $4 \mathrm{R}-1$ & IW-3 & 10R-1 & $12 \mathrm{R}-5$ & 13R-2 & 14R-3 & $7 \mathrm{R}-2$ & $12 \mathrm{R}-1$ & 12R-3 & $6 \mathrm{R}-3$ \\
\hline Interval $(\mathrm{cm})$ : & $66-72$ & $18-23$ & $84-90$ & $114-120$ & $20-26$ & $82-89$ & $129-136$ & $70-73$ & $102-108$ & $23-28$ & $107-114$ & $7-12$ & $71-78$ & $73-78$ & $29-35$ & $63-68$ \\
\hline$n:$ & 7 & 10 & 3 & 7 & 3 & 5 & 5 & 9 & 9 & 9 & 11 & 14 & 7 & 13 & 8 & 5 \\
\hline $\mathrm{SiO}_{2}$ & 0.01 & 0.02 & 0.01 & 0.02 & 0.63 & 0.05 & 0.04 & 0.05 & 0.04 & 0.01 & 0.02 & 0.06 & 0.21 & 0.01 & 0.02 & 0.01 \\
\hline $\mathrm{TiO}_{2}$ & 0.05 & 0.04 & 0.03 & 0.05 & 0.03 & 0.07 & 0.07 & 0.03 & 0.04 & 0.03 & 0.05 & 0.03 & 0.04 & 0.05 & 0.06 & 0.04 \\
\hline $\mathrm{Al}_{2} \mathrm{O}_{3}$ & 45.13 & 44.29 & 43.99 & 44.18 & 45.16 & 42.57 & 42.78 & 45.36 & 42.90 & 42.84 & 43.47 & 43.54 & 44.27 & 42.73 & 43.86 & 48.25 \\
\hline $\mathrm{Cr}_{2} \mathrm{O}_{3}$ & 24.43 & 25.12 & 24.25 & 24.60 & 21.99 & 25.57 & 25.41 & 22.91 & 25.07 & 24.80 & 25.47 & 24.93 & 23.54 & 26.23 & 25.37 & 20.57 \\
\hline $\mathrm{FeO}$ & 13.41 & 13.42 & 13.93 & 13.42 & 13.83 & 13.05 & 12.77 & 13.20 & 13.78 & 13.72 & 13.40 & 14.31 & 13.58 & 13.91 & 13.32 & 12.63 \\
\hline $\mathrm{MnO}$ & 0.17 & 0.16 & 0.17 & 0.16 & 0.15 & 0.18 & 0.17 & 0.14 & 0.18 & 0.18 & 0.17 & 0.16 & 0.14 & 0.16 & 0.18 & 0.14 \\
\hline $\mathrm{NiO}$ & 0.21 & 0.20 & 0.19 & 0.22 & 0.17 & 0.20 & 0.19 & 0.23 & 0.22 & 0.18 & 0.22 & 0.19 & 0.20 & 0.19 & 0.21 & 0.21 \\
\hline $\mathrm{MgO}$ & 17.55 & 17.50 & 15.83 & 16.42 & 17.65 & 17.37 & 17.38 & 17.80 & 17.54 & 17.34 & 16.32 & 16.99 & 17.22 & 17.15 & 16.27 & 17.94 \\
\hline $\mathrm{CaO}$ & 0.01 & 0.01 & 0.01 & 0.00 & 0.00 & 0.02 & 0.00 & 0.01 & 0.01 & 0.01 & 0.00 & 0.01 & 0.01 & 0.01 & 0.01 & 0.06 \\
\hline $\mathrm{Na}_{2} \mathrm{O}$ & 0.00 & 0.00 & 0.00 & 0.00 & 0.00 & 0.00 & 0.03 & 0.00 & 0.00 & 0.00 & 0.01 & 0.00 & 0.00 & 0.01 & 0.00 & 0.00 \\
\hline $\mathrm{K}_{2} \mathrm{O}$ & 0.00 & 0.00 & 0.01 & 0.00 & 0.00 & 0.00 & 0.01 & 0.00 & 0.00 & 0.01 & 0.00 & 0.00 & 0.01 & 0.00 & 0.00 & 0.01 \\
\hline $\mathrm{Si}$ & $\begin{array}{l}0.000 \\
0.001\end{array}$ & 0.001 & 0.001 & 0.001 & 0.018 & $\begin{array}{l}0.000 \\
0.002\end{array}$ & 0.001 & $\begin{array}{l}0.001 \\
0.001\end{array}$ & 0.001 & $\begin{array}{l}0.000 \\
0.001\end{array}$ & 0.001 & 0.002 & 0.007 & 0.000 & 0.001 & 0.000 \\
\hline $\mathrm{Ti}$ & 0.001 & 0.001 & & & 0.001 & 0.002 & 0.001 & 0.001 & 0.001 & 0.001 & 0.001 & 0.001 & 0.001 & 0.001 & 0.001 & 0.001 \\
\hline $\mathrm{Al}$ & 1.451 & 1.431 & 1.464 & 1.443 & 1,463 & 1.412 & 1.412 & 1.469 & 1.406 & 1.414 & 1.427 & 1.421 & 1.450 & 1.395 & 1.441 & 1.541 \\
\hline $\mathrm{Cr}$ & 0.526 & 0.545 & 0.535 & 0.548 & 0.477 & 0.560 & 0.560 & 0.498 & 0.550 & 0.549 & 0.566 & 0.546 & 0.513 & 0.575 & 0.560 & 0.442 \\
\hline $\mathrm{Fe}^{2+}$ & 0.306 & 0.308 & 0.330 & 0.311 & 0.318 & 0.298 & 0.301 & 0.304 & 0.321 & 0.320 & 0.313 & 0.332 & 0.311 & 0.323 & 0.311 & 0.287 \\
\hline $\mathrm{Mn}$ & 0.004 & 0.004 & 0.005 & 0.004 & 0.004 & 0.004 & 0.004 & 0.003 & 0.004 & 0.004 & 0.004 & 0.004 & 0.003 & 0.004 & 0.004 & 0.003 \\
\hline $\mathrm{Ni}$ & 0.005 & 0.005 & 0.005 & 0.005 & 0.004 & 0.005 & 0.005 & 0.005 & 0.005 & 0.004 & 0.005 & 0.004 & 0.005 & 0.004 & 0.004 & 0.004 \\
\hline $\mathrm{Mg}$ & 0.714 & 0.716 & 0.662 & 0.685 & 0.724 & 0.729 & 0.725 & 0.730 & 0.728 & 0.724 & 0.681 & 0.702 & 0.716 & 0.709 & 0.676 & 0.725 \\
\hline $\mathrm{Ca}$ & 0.000 & 0.000 & 0.000 & 0.000 & 0.000 & 0.000 & 0.000 & 0.000 & 0.000 & 0.000 & 0.000 & 0.001 & 0.000 & 0.000 & 0.000 & 0.002 \\
\hline $\mathrm{Na}$ & 0.000 & 0.000 & 0.001 & 0.000 & 0.000 & 0.000 & 0.000 & 0.000 & 0.000 & 0.000 & 0.000 & 0.000 & 0.000 & 0.000 & 0.000 & 0.000 \\
\hline $\mathrm{K}$ & 0.000 & 0.000 & 0.000 & 0.000 & 0.000 & 0.000 & 0.000 & 0.000 & 0.000 & 0.000 & 0.000 & 0.000 & 0.000 & 0.000 & 0.000 & 0.000 \\
\hline $\mathrm{Mg \#}$ & $\begin{array}{r}69.99 \\
26.60\end{array}$ & $\begin{array}{l}69.92 \\
27.59\end{array}$ & $\begin{array}{l}66.77 \\
26.76\end{array}$ & $\begin{array}{l}68.76 \\
27.53\end{array}$ & $\begin{array}{r}69.48 \\
24.58\end{array}$ & $\begin{array}{l}71.01 \\
28.39\end{array}$ & $\begin{array}{r}70.65 \\
28.40\end{array}$ & $\begin{array}{r}70.60 \\
25.31\end{array}$ & $\begin{array}{l}69.42 \\
28.12\end{array}$ & $\begin{array}{r}69.33 \\
27.96\end{array}$ & $\begin{array}{l}68.49 \\
28.39\end{array}$ & $\begin{array}{r}67.90 \\
27.74\end{array}$ & 69.73 & 68.72 & $\begin{array}{l}68.51 \\
27.99\end{array}$ & $\begin{array}{l}71.67 \\
22.29\end{array}$ \\
\hline & 26.60 & & & 27.53 & 24.58 & & & & & 27.96 & 28.39 & 27.74 & & 29.17 & 27.99 & \\
\hline
\end{tabular}

Notes: All data are in weight percent ( $\mathrm{w} t \%)$; molecular formula was calculated for $\mathrm{O}=4 ; n=$ number of analyses.

Table 6 (continued).

\begin{tabular}{|c|c|c|c|c|c|c|c|c|c|c|c|c|c|c|c|c|}
\hline Hole: & 153-920D & 153-920D & 153-920D & $153-920 \mathrm{D}$ & 153-920D & $153-920 \mathrm{D}$ & 153-920D & 153-920D & 153-920D & 153-920D & $153-920 \mathrm{D}$ & 153-920D & 153-920D & 153-920D & 153-920D & Average \\
\hline Core, section: & $12 \mathrm{R}-3$ & $5 \mathrm{R}-2$ & $2 \mathrm{R}-2$ & $14 R-4$ & $15 \mathrm{R}-1$ & $16 \mathrm{R}-3$ & $22 \mathrm{R}-5$ & $22 \mathrm{R}-3$ & $18 \mathrm{R}-2$ & $15 R-3$ & 20R-5 & $15 \mathrm{R}-3$ & $22 \mathrm{R}-2$ & $15 \mathrm{R}-5$ & $22 \mathrm{R}-5$ & \\
\hline Interval $(\mathrm{cm})$ : & $35-39$ & $76-82$ & $33-38$ & $76-82$ & $8-15$ & $64-70$ & $11-116$ & $19-23$ & $35-41$ & $36-40$ & $54-60$ & $114-119$ & $69-73$ & $14-22$ & $3-9$ & \\
\hline$n:$ & 10 & 13 & 11 & 15 & 21 & 21 & 17 & 13 & 4 & 12 & 9 & 7 & 15 & 23 & 14 & 336 \\
\hline $\mathrm{SiO}_{2}$ & 0.02 & 0.04 & 0.01 & 0.01 & 0.03 & 0.02 & 0.02 & 0.02 & 0.02 & 0.03 & 0.00 & 0.36 & 0.01 & 0.01 & 0.02 & 0.04 \\
\hline $\begin{array}{l}\mathrm{TiO}_{2} \\
\mathrm{TiO}_{2}\end{array}$ & 0.05 & 0.06 & 0.06 & 0.03 & 0.04 & 0.05 & 0.06 & 0.05 & 0.05 & 0.05 & 0.03 & 0.04 & 0.05 & 0.05 & 0.04 & 0.05 \\
\hline $\mathrm{Al}_{2} \mathrm{O}_{3}$ & 43.59 & 43.57 & 42.34 & 44.02 & 42.51 & 43.25 & 42.06 & $\begin{array}{r}0.03 \\
42.59\end{array}$ & $\begin{array}{r}0.03 \\
43.19\end{array}$ & 41.66 & $\begin{array}{r}0.03 \\
45.64\end{array}$ & $\begin{array}{r}0.04 \\
41.67\end{array}$ & $\begin{array}{r}0.05 \\
42.57\end{array}$ & $\begin{array}{r}0.03 \\
43.56\end{array}$ & $\begin{array}{r}0.04 \\
43.72\end{array}$ & 43.35 \\
\hline $\begin{array}{l}\mathrm{A}_{2} \mathrm{O}_{3} \\
\mathrm{Cr}_{2} \mathrm{O}_{3}\end{array}$ & 24.68 & 25.42 & $\begin{array}{l}26.44 \\
26.40\end{array}$ & 24.54 & $\begin{array}{l}42.51 \\
25.52\end{array}$ & 25.38 & $\begin{array}{l}42.00 \\
24.89\end{array}$ & 25.11 & 25.23 & $\begin{array}{l}25.85 \\
25.85\end{array}$ & 22.81 & $\begin{array}{l}24.01 \\
24.48\end{array}$ & 25.23 & $\begin{array}{l}\begin{array}{r}43.50 \\
24.69\end{array}\end{array}$ & 24.79 & 24.92 \\
\hline $\mathrm{FeO}$ & 13.15 & 13.23 & 14.34 & 13.92 & 13.86 & 13.48 & 14.28 & 13.34 & 13.81 & 15.09 & 13.29 & 16.24 & 13.97 & 13.84 & 13.42 & 13.75 \\
\hline $\mathrm{MnO}$ & 0.18 & 0.16 & 0.16 & 0.16 & 0.17 & 0.16 & $\begin{array}{r}0.17 \\
0.17\end{array}$ & 0.16 & 0.16 & 0.19 & 0.14 & $\begin{array}{r}10.24 \\
0.19\end{array}$ & 0.17 & 0.17 & $\begin{array}{r}11.42 \\
0.16\end{array}$ & 0.17 \\
\hline $\mathrm{NiO}$ & 0.20 & 0.19 & 0.19 & 0.20 & 0.21 & 0.21 & 0.23 & 0.20 & 0.20 & 0.20 & 0.21 & 0.20 & 0.21 & 0.20 & 0.24 & 0.21 \\
\hline $\mathrm{MgO}$ & 17.53 & 17.58 & 16.91 & 17.24 & 17.22 & 17.46 & 16.77 & 17.15 & 17.30 & 16.19 & 17.48 & 16.87 & 16.71 & 17.19 & 17.78 & 17.16 \\
\hline $\mathrm{CaO}$ & 0.00 & 0.01 & 0.00 & 0.01 & 0.01 & 0.01 & 0.01 & 0.00 & 0.01 & 0.04 & 0.01 & 0.01 & 0.01 & 0.01 & 0.03 & 0.01 \\
\hline $\mathrm{Na}_{2} \mathrm{O}$ & 0.00 & 0.01 & 0.00 & 0.00 & 0.02 & 0.00 & 0.01 & 0.01 & 0.00 & 0.02 & 0.01 & 0.00 & 0.01 & 0.00 & 0.01 & 0.01 \\
\hline $\mathrm{K}_{2} \mathrm{O}$ & 0.00 & 0.00 & 0.00 & 0.01 & 0.01 & 0.00 & 0.00 & 0.01 & 0.00 & 0.01 & 0.00 & 0.00 & 0.00 & 0.00 & 0.01 & 0.00 \\
\hline $\mathrm{Si}$ & 0.001 & 0.001 & 0.000 & 0.000 & 0.001 & 0.000 & 0.001 & 0.001 & 0.001 & 0.001 & 0.000 & 0.011 & 0.000 & 0.000 & 0.001 & 0.001 \\
\hline $\mathrm{Ti}$ & 0.001 & 0.001 & 0.001 & 0.000 & 0.001 & 0.001 & 0.001 & 0.001 & 0.001 & 0.001 & 0.001 & 0.001 & 0.001 & 0.001 & 0.001 & 0.001 \\
\hline $\mathrm{Al}$ & $\begin{array}{l}1.426 \\
0.541\end{array}$ & $\begin{array}{l}1.416 \\
0.554\end{array}$ & $\begin{array}{l}1.387 \\
0.579\end{array}$ & $\begin{array}{l}1.433 \\
0536\end{array}$ & $\begin{array}{l}1.399 \\
0563\end{array}$ & 1.412 & $\begin{array}{l}1.423 \\
0541\end{array}$ & $\begin{array}{l}1.408 \\
0.559\end{array}$ & $\begin{array}{l}1.413 \\
0.553\end{array}$ & $\begin{array}{l}1.392 \\
0.573\end{array}$ & 1.479 & $\begin{array}{l}1.375 \\
0541\end{array}$ & 1.397 & 1.426 & 1.421 & 1.421 \\
\hline $\mathrm{Fe}^{2+}$ & $\begin{array}{l}0.341 \\
0.305\end{array}$ & $\begin{array}{l}0.354 \\
0.305\end{array}$ & $\begin{array}{l}0.379 \\
0.334\end{array}$ & $\begin{array}{l}0.536 \\
0.322\end{array}$ & $\begin{array}{l}0.363 \\
0.324\end{array}$ & $\begin{array}{l}0.356 \\
0.312\end{array}$ & $\begin{array}{l}0.541 \\
0.338\end{array}$ & $\begin{array}{l}0.359 \\
0.315\end{array}$ & $\begin{array}{l}0.333 \\
0.321\end{array}$ & $\begin{array}{l}0.973 \\
0.346\end{array}$ & $\begin{array}{l}0.496 \\
0.306\end{array}$ & $\begin{array}{l}0.341 \\
0.384\end{array}$ & $\begin{array}{l}0.372 \\
0.334\end{array}$ & $\begin{array}{l}0.542 \\
0.322\end{array}$ & $\begin{array}{l}0.541 \\
0.310\end{array}$ & $\begin{array}{l}0.547 \\
0.320\end{array}$ \\
\hline $\mathrm{Mn}$ & 0.004 & 0.004 & 0.004 & 0.004 & 0.004 & 0.004 & 0.004 & 0.004 & 0.004 & 0.004 & 0.003 & 0.004 & 0.004 & 0.004 & 0.004 & 0.004 \\
\hline $\mathrm{Ni}$ & 0.004 & 0.004 & 0.004 & 0.005 & 0.005 & 0.005 & 0.005 & 0.005 & 0.005 & 0.005 & 0.005 & 0.005 & 0.005 & 0.004 & 0.005 & 0.005 \\
\hline $\mathrm{Mg}$ & 0.726 & 0.723 & 0.701 & 0.711 & 0.717 & 0.722 & 0.7 & 0.7 & 0.71 & 0.68 & 0.71 & 0.7 & 0.6 & 0.7 & 0.732 & 0.712 \\
\hline $\mathrm{Ca}$ & 0.000 & 0.000 & 0.000 & 0.000 & 0.000 & 0.000 & 0.00 & 0.0 & 0.000 & 0.001 & 0.000 & 0.0 & 0.0 & 0.0 & 0.001 & 0.000 \\
\hline $\mathrm{Na}$ & 0.000 & 0.001 & 0.000 & 0.000 & 0.001 & 0.000 & 0.001 & 0.001 & 0.000 & 0.001 & 0.000 & 0.000 & 0.000 & 0.000 & 0.001 & 0.000 \\
\hline $\mathrm{K}$ & 0.000 & 0.000 & 0.000 & 0.000 & 0.000 & 0.000 & 0.000 & 0.000 & 0.000 & 0.000 & 0.000 & 0.000 & 0.000 & 0.000 & 0.000 & 0.000 \\
\hline Mg\# & 70.39 & 70.31 & 67.74 & 68.81 & 68.89 & 69.79 & 67.48 & 69.50 & 69.09 & 66.55 & 70.11 & 64.72 & 67.67 & 68.89 & 70.25 & 69.03 \\
\hline $\mathrm{Cr} /(\mathrm{Cr}+\mathrm{Al})$ & 27.51 & 28.12 & 29.45 & 27.22 & 28.71 & 28.26 & 27.56 & 28.41 & 28.11 & 29.15 & 25.09 & 28.25 & 29.07 & 27.55 & 27.59 & 27.79 \\
\hline
\end{tabular}



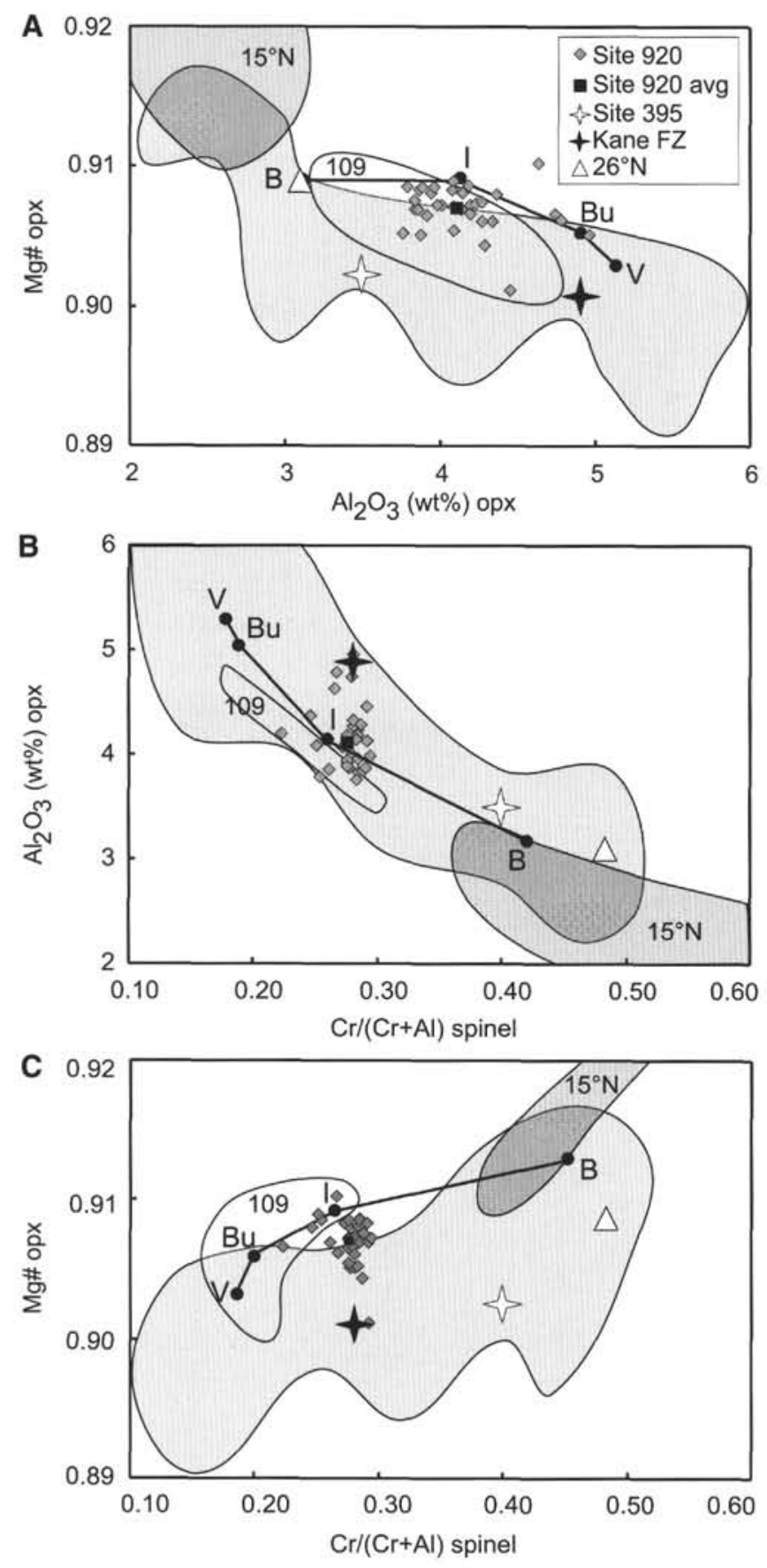

Figure 4. Site 920 orthopyroxene and spinel compositions plotted vs. the fields for North Atlantic peridotites of Michael and Bonatti (1985, shaded field). Site 395 , Kane Fracture Zone (FZ), and $26^{\circ} \mathrm{N}$ are averages from the data of Michael and Bonatti (1985). V, Bu, I, and B are averaged compositions for Southwest Indian Ridge (SWIR) and American-Antarctic Ridge (AAR) fracture zone peridotites $(\mathrm{V}=$ Vulcan, $\mathrm{Bu}=$ Bullard, $\mathrm{I}=$ Islas Orcadas, $\mathrm{B}=$ Bouvet) from Dick et al. (1989). Field marked 109 is Hole 670A (ODP Leg 109) data from Juteau et al., 1990; field marked $15^{\circ} \mathrm{N}$ contains data from Cannat and Casey (1995) from Cape Verde Fracture Zone. A. Mg\# in orthopyroxene vs. $\mathrm{Al}_{2} \mathrm{O}_{3}$ in orthopyroxene. $\mathbf{B}$. $\mathrm{Al}_{2} \mathrm{O}_{3}$ in orthopyroxene vs. $\mathrm{Cr} \#$ in spinel. C. Mg\# in orthopyroxene vs. $\mathrm{Cr} \#$ in spinel.

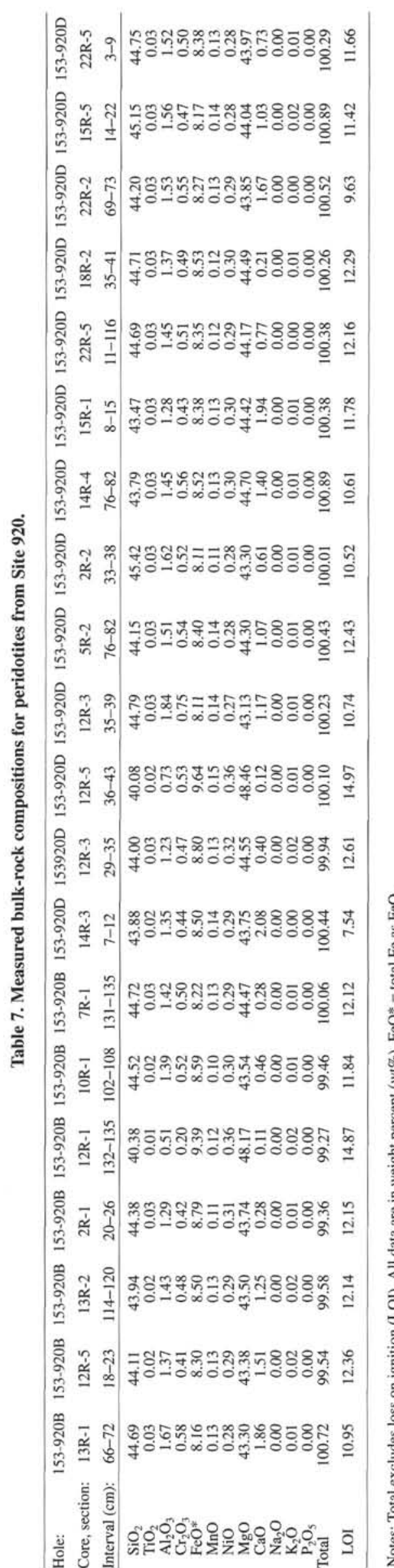


Table 8. Calculated bulk-rock compositions of spinel peridotite from Site 920.

\begin{tabular}{|c|c|c|c|c|c|c|c|c|c|c|c|c|}
\hline Hole: & $153-920 \mathrm{~B}$ & $153-920 \mathrm{~B}$ & $153-920 \mathrm{~B}$ & $153-920 \mathrm{~B}$ & $153-920 \mathrm{~B}$ & $153-920 \mathrm{D}$ & $153-920 \mathrm{D}$ & $153-920 \mathrm{D}$ & $153-920 \mathrm{D}$ & $153-920 \mathrm{D}$ & 153-920D & $153-920 \mathrm{D}$ \\
\hline Core, section: & $13 R-1$ & $12 \mathrm{R}-5$ & $12 R-4$ & $2 \mathrm{R}-1$ & $10 \mathrm{R}-1$ & $14 \mathrm{R}-3$ & $12 \mathrm{R}-3$ & $12 \mathrm{R}-3$ & $5 R-2$ & $2 \mathrm{R}-2$ & $14 R-4$ & $15 R-1$ \\
\hline Interval $(\mathrm{cm})$ : & $66-72$ & $18-23$ & $84-90$ & $20-26$ & $102-108$ & $7-12$ & $29-35$ & $35-39$ & $76-82$ & $33-38$ & $76-82$ & $8-15$ \\
\hline $\begin{array}{l}\mathrm{SiO}_{2} \\
\mathrm{TiO}_{2} \\
\mathrm{Al}_{2} \mathrm{O}_{3} \\
\mathrm{Cr}_{2} \mathrm{O}_{3} \\
\mathrm{FeO} \\
\mathrm{MnO} \\
\mathrm{NiO} \\
\mathrm{MgO} \\
\mathrm{CaO} \\
\mathrm{Na}_{2} \mathrm{O} \\
\mathrm{K}_{2} \mathrm{O}\end{array}$ & $\begin{array}{r}43.51 \\
0.01 \\
1.13 \\
0.35 \\
8.43 \\
0.12 \\
0.31 \\
46.57 \\
0.60 \\
0.01 \\
0.00\end{array}$ & $\begin{array}{r}39.58 \\
0.01 \\
2.10 \\
1.16 \\
9.20 \\
0.13 \\
0.36 \\
48.18 \\
0.26 \\
0.00 \\
0.01\end{array}$ & $\begin{array}{r}42.65 \\
0.01 \\
0.81 \\
0.23 \\
8.46 \\
0.13 \\
0.32 \\
45.11 \\
1.67 \\
0.02 \\
0.00\end{array}$ & $\begin{array}{r}45.44 \\
0.02 \\
1.47 \\
0.43 \\
7.88 \\
0.14 \\
0.30 \\
45.39 \\
0.31 \\
0.01 \\
0.00\end{array}$ & $\begin{array}{r}43.01 \\
0.02 \\
1.34 \\
0.54 \\
8.74 \\
0.14 \\
0.33 \\
47.11 \\
0.28 \\
0.01 \\
0.00\end{array}$ & $\begin{array}{r}43.98 \\
0.02 \\
1.21 \\
0.36 \\
8.48 \\
0.13 \\
0.30 \\
45.01 \\
1.41 \\
0.01 \\
0.00\end{array}$ & $\begin{array}{r}42.68 \\
0.01 \\
1.12 \\
0.43 \\
8.58 \\
0.13 \\
0.34 \\
46.22 \\
0.54 \\
0.01 \\
0.00\end{array}$ & $\begin{array}{r}43.24 \\
0.02 \\
1.15 \\
0.40 \\
8.63 \\
0.12 \\
0.30 \\
46.37 \\
0.78 \\
0.01 \\
0.00\end{array}$ & $\begin{array}{r}41.11 \\
0.01 \\
1.79 \\
0.80 \\
8.78 \\
0.13 \\
0.33 \\
46.59 \\
0.81 \\
0.01 \\
0.01\end{array}$ & $\begin{array}{r}42.58 \\
0.02 \\
1.20 \\
0.55 \\
9.14 \\
0.13 \\
0.33 \\
47.66 \\
0.33 \\
0.01 \\
0.00\end{array}$ & $\begin{array}{r}44.95 \\
0.02 \\
1.44 \\
0.37 \\
8.09 \\
0.13 \\
0.29 \\
44.56 \\
1.12 \\
0.01 \\
0.00\end{array}$ & $\begin{array}{r}44.50 \\
0.02 \\
1.58 \\
0.47 \\
8.28 \\
0.13 \\
0.30 \\
44.22 \\
1.03 \\
0.02 \\
0.01\end{array}$ \\
\hline Hole: & 153-920D & $153-920 \mathrm{D}$ & 153-920D & 153-920D & $153-920 \mathrm{D}$ & 153-920D & Average & Vulcan & Bouvet & Bullard & Islas Orcadas & \\
\hline Core, section: & $16 \mathrm{R}-3$ & $22 \mathrm{R}-5$ & $18 \mathrm{R}-2$ & $22 \mathrm{R}-2$ & $15 R-5$ & $22 \mathrm{R}-5$ & & & & & & \\
\hline Interval $(\mathrm{cm})$ : & $64-70$ & $11-116$ & $35-41$ & $69-73$ & $14-22$ & $3-9$ & & & & & & \\
\hline $\begin{array}{l}\mathrm{SiO}_{2} \\
\mathrm{TiO}_{2} \\
\mathrm{Al}_{2} \mathrm{O}_{3} \\
\mathrm{Cr}_{2} \mathrm{O}_{3} \\
\mathrm{FeO} \\
\mathrm{MnO} \\
\mathrm{NiO} \\
\mathrm{MgO} \\
\mathrm{CaO} \\
\mathrm{Na}_{2} \mathrm{O} \\
\mathrm{K}_{2} \mathrm{O}\end{array}$ & $\begin{array}{r}43.32 \\
0.02 \\
1.58 \\
0.62 \\
8.39 \\
0.13 \\
0.32 \\
46.07 \\
1.06 \\
0.02 \\
0.01\end{array}$ & $\begin{array}{r}43.44 \\
0.01 \\
1.45 \\
0.53 \\
8.35 \\
0.14 \\
0.32 \\
45.72 \\
0.78 \\
0.01 \\
0.01\end{array}$ & $\begin{array}{r}44.09 \\
0.02 \\
1.61 \\
0.49 \\
8.43 \\
0.14 \\
0.32 \\
45.26 \\
0.53 \\
0.01 \\
0.00\end{array}$ & $\begin{array}{r}40.65 \\
0.01 \\
1.51 \\
0.77 \\
8.79 \\
0.13 \\
0.35 \\
46.95 \\
0.91 \\
0.03 \\
0.01\end{array}$ & $\begin{array}{r}42.11 \\
0.02 \\
1.13 \\
0.46 \\
8.61 \\
0.13 \\
0.34 \\
47.17 \\
0.75 \\
0.01 \\
0.00\end{array}$ & $\begin{array}{r}45.41 \\
0.02 \\
1.93 \\
0.49 \\
7.85 \\
0.14 \\
0.28 \\
41.88 \\
1.27 \\
0.01 \\
0.01\end{array}$ & $\begin{array}{r}43.12 \\
0.02 \\
1.42 \\
0.53 \\
8.51 \\
0.13 \\
0.32 \\
45.89 \\
0.80 \\
0.01 \\
0.01\end{array}$ & $\begin{array}{r}43.65 \\
0.03 \\
1.96 \\
0.36 \\
8.43 \\
0.15 \\
0.22 \\
42.87 \\
1.99 \\
0.05 \\
0.01\end{array}$ & $\begin{array}{r}42.97 \\
0.00 \\
0.79 \\
0.25 \\
8.27 \\
0.12 \\
0.25 \\
45.83 \\
0.76 \\
0.01 \\
0.00\end{array}$ & $\begin{array}{r}43.74 \\
0.01 \\
1.33 \\
0.33 \\
8.25 \\
0.15 \\
0.25 \\
44.29 \\
1.45 \\
0.02 \\
0.00\end{array}$ & $\begin{array}{r}43.67 \\
0.02 \\
1.71 \\
0.31 \\
8.31 \\
0.13 \\
0.21 \\
43.61 \\
1.41 \\
0.05 \\
0.00\end{array}$ & \\
\hline
\end{tabular}

Notes: Compositions are calculated from analyzed mineral compositions from Tables 3 through 6 , modal data from Table 2 , and specific gravities of $3.34,3.30,3.30$, and $4.30 \mathrm{~g}$ cm ${ }^{-3}$, respectively, for olivine, orthopyroxene, clinopyroxene, and spinel. Also tabled are the calculated average spinel peridotite compositions for the AAR and Southwest Indian Ridge peridotites from Dick (1989). All data are in weight percent (wt\%).

A

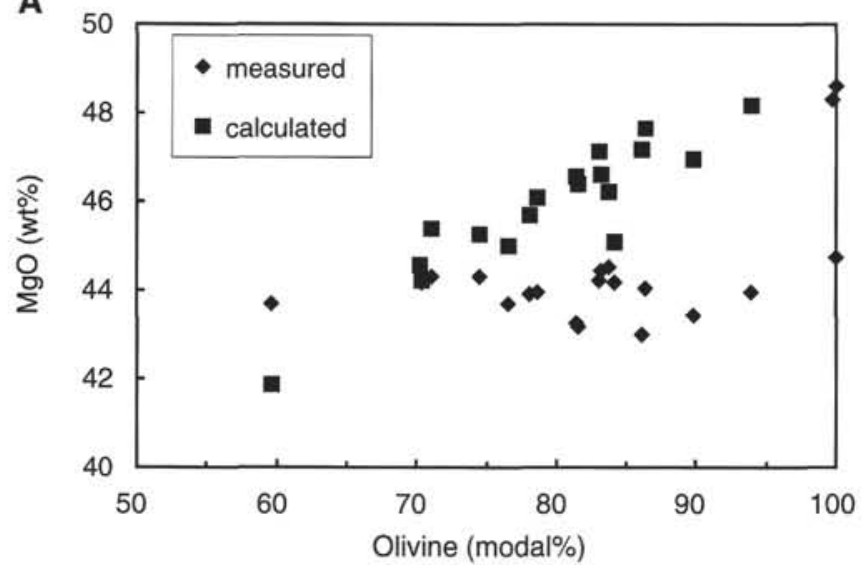

B

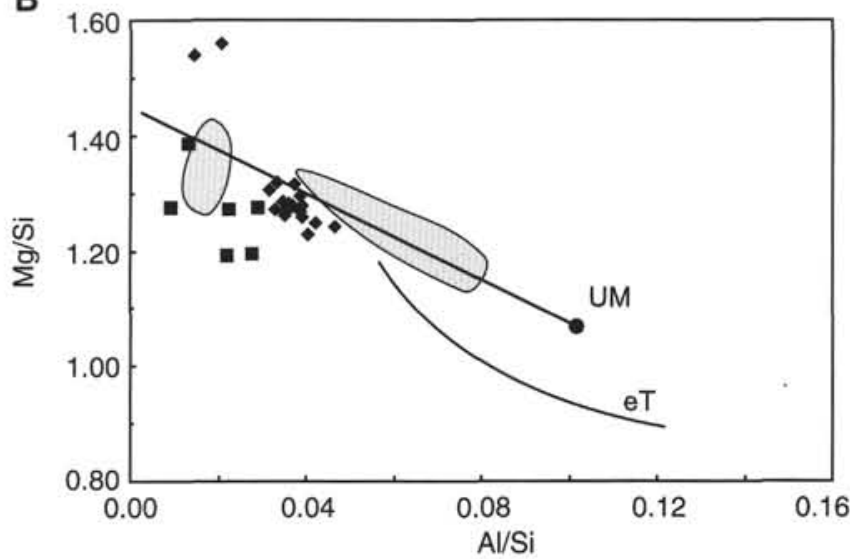

Figure 5. A. Comparison of measured and calculated $\mathrm{MgO}$ contents for Site 920 peridotites, showing the uniform measured composition and dependence of calculated composition on the modal estimate. B. $\mathrm{Mg} / \mathrm{Si}$ vs. Al/Si (wt\%) for Site 920 peridotites (diamonds). Data from Mid-Atlantic Ridge $43^{\circ} \mathrm{N}$ (squares) from Shibata and Thompson (1986). Shaded fields are from Trinity Ophiolite (Quick, 1981; Jacobsen et al., 1984; Gruau et al., 1991); curved line marked eT joins enriched Trinity Ophiolite data of Gruau et al. (1995); heavy line shows trend of melt depletion from Gruau et al. (1995); undepleted mantle (UM) composition is from Gruau et al. (1995), after Jacobsen et al. (1984) and Jagoutz et al. (1979). 
Table 9. Trace-element ICP-MS analyses for peridotites from Site $\mathbf{9 2 0 .}$

\begin{tabular}{|c|c|c|c|c|c|c|c|c|c|c|c|}
\hline Hole: & 153-920B & 153-920B & 153-920B & $153-920 B$ & $153-920 \mathrm{~B}$ & $153-920 \mathrm{~B}$ & $153-920 \mathrm{~B}$ & $153-920 \mathrm{D}$ & I53-920D & 153-920D & $153-920 \mathrm{D}$ \\
\hline Core, section: & 13R-1 & $12 \mathrm{R}-5$ & $12 \mathrm{R}-4$ & $2 \mathrm{R}-1$ & $12 \mathrm{R}-1$ & $10 \mathrm{R}-1$ & $7 \mathrm{R}-1$ & $14 \mathrm{R}-3$ & $12 \mathrm{R}-3$ & $12 \mathrm{R}-5$ & $12 \mathrm{R}-3$ \\
\hline Interval $(\mathrm{cm})$ : & $66-72$ & $18-23$ & $84-90$ & $20-26$ & $132-135$ & $102-108$ & $131-135$ & $7-12$ & $29-35$ & $36-43$ & $35-39$ \\
\hline $\mathrm{Y}$ & 0.6782 & 0.5551 & 0.5160 & 0.4896 & 0.0518 & 0.4405 & 0.4773 & 0.5669 & 0.5188 & 0.0735 & 0.7178 \\
\hline $\mathrm{Zr}$ & 0.0605 & 0.0301 & 0.0710 & 0.0519 & 0.1962 & 0.0558 & 0.0474 & 0.1115 & 0.0394 & 0.0845 & 0.1663 \\
\hline $\mathrm{Nb}$ & 0.0085 & 0.0040 & 0.0085 & 0.0018 & 0.0035 & 0.0076 & 0.0052 & 0.0072 & 0.0037 & 0.0031 & 0.0099 \\
\hline $\mathrm{Ta}$ & 0.0090 & 0.0021 & 0.0047 & 0.0019 & 0.0100 & 0.0008 & 0.0011 & 0.0027 & 0.0000 & 0.0076 & 0.0000 \\
\hline $\mathrm{La}$ & 0.0000 & 0.0000 & 0.0286 & 0.0000 & 0.0005 & 0.0007 & 0.0040 & 0.0129 & 0.0000 & 0.0000 & 0.0229 \\
\hline $\mathrm{Ce}$ & 0.0000 & 0.0000 & 0.1062 & 0.0000 & 0.0027 & 0.0080 & 0.0088 & 0.0246 & 0.0000 & 0.0000 & 0.0515 \\
\hline $\mathrm{Pr}$ & 0.0004 & 0.0000 & 0.0145 & 0.0004 & 0.0009 & 0.0016 & 0.0019 & 0.0040 & 0.0008 & 0.0005 & 0.0071 \\
\hline $\mathrm{Nd}$ & 0.0021 & 0.0014 & 0.0515 & 0.0008 & 0.0038 & 0.0079 & 0.0074 & 0.0164 & 0.0044 & 0.0020 & 0.0309 \\
\hline Sm & 0.0116 & 0.0072 & 0.0152 & 0.0105 & 0.0059 & 0.0077 & 0.0096 & 0.0112 & 0.0099 & 0.0042 & 0.0154 \\
\hline $\mathrm{Eu}$ & 0.0056 & 0.0048 & 0.0047 & 0.0063 & 0.0213 & 0.0118 & 0.0091 & 0.0049 & 0.0051 & 0.0025 & 0.0061 \\
\hline $\mathrm{Gd}$ & 0.0365 & 0.0291 & 0.0316 & 0.0251 & 0.0072 & 0.0219 & 0.0235 & 0.0334 & 0.0307 & 0.0073 & 0.0367 \\
\hline $\mathrm{Tb}$ & 0.0070 & 0.0046 & 0.0053 & 0.0036 & 0.0000 & 0.0024 & 0.0032 & 0.0047 & 0.0043 & 0.0000 & 0.0064 \\
\hline Dy & 0.0867 & 0.0689 & 0.0657 & 0.0656 & 0.0062 & 0.0565 & 0.0554 & 0.0695 & 0.0698 & 0.0088 & 0.0887 \\
\hline Ho & 0.0237 & 0.0199 & 0.0187 & 0.0176 & 0.0016 & 0.0150 & 0.0165 & 0.0200 & 0.0186 & 0.0026 & 0.0256 \\
\hline Er & 0.0881 & 0.0720 & 0.0694 & 0.0657 & 0.0091 & 0.0569 & 0.0629 & 0.0728 & 0.0662 & 0.0112 & 0.0899 \\
\hline $\mathrm{Tm}$ & 0.0149 & 0.0127 & 0.0120 & 0.0112 & 0.0020 & 0.0108 & 0.0116 & 0.0127 & 0.0108 & 0.0026 & 0.0151 \\
\hline $\mathrm{Yb}$ & 0.1151 & 0.0992 & 0.0948 & 0.0863 & 0.0196 & 0.0825 & 0.0884 & 0.0979 & 0.0826 & 0.0215 & 0.1224 \\
\hline $\mathrm{Lu}$ & 0.0192 & 0.0179 & 0.0177 & 0.0160 & 0.0048 & 0.0148 & 0.0165 & 0.0180 & 0.0148 & 0.0046 & 0.0213 \\
\hline $\mathrm{Hf}$ & 0.0060 & 0.0047 & 0.0058 & 0.0057 & 0.0073 & 0.0052 & 0.0060 & 0.0073 & 0.0051 & 0.0035 & 0.0073 \\
\hline $\mathrm{Li}$ & 1.2461 & 0.5189 & 0.6542 & 0.2950 & 0.0237 & 1.0384 & 0.5951 & 0.8878 & 0.2797 & 0.0084 & 0.7486 \\
\hline $\mathrm{Be}$ & 0.0000 & 0.0000 & 0.0006 & 0.0000 & 0.0637 & 0.0135 & 0.0030 & 0.0000 & 0.0000 & 0.0001 & 0.0076 \\
\hline Sc & 17.5716 & 17.6089 & 18.1989 & 16.7724 & 7.3434 & 16.7505 & 14.6480 & 17.5275 & 13.9819 & 6.4896 & 20.8737 \\
\hline V & 63.2571 & 55.7906 & 61.8518 & 56.1756 & 13.8474 & 54.9105 & 56.2365 & 58.6005 & 49.4141 & 24.1894 & 76.1964 \\
\hline Co & 117.7581 & 119.7284 & 135.7229 & 136.1796 & 163.4525 & 128.9862 & 129.9715 & 128.4725 & 132.7437 & 159.1360 & 122.3752 \\
\hline $\mathrm{Cu}$ & 19.2535 & 15.6425 & 20.0479 & 3.9213 & 10.1246 & 16.7465 & 21.8057 & 20.0057 & 38.3778 & 7.3632 & 21.6768 \\
\hline $\mathrm{Zn}$ & 35.4819 & 34.1517 & 43.1901 & 34.7233 & 36.9144 & 33.4928 & 37.4260 & 39.3542 & 40.5372 & 48.0528 & 41.5169 \\
\hline $\mathrm{Ga}$ & 1.4654 & 1.2830 & 1.6321 & 1.4563 & 0.9304 & 1.6579 & 1.5820 & 1.5058 & 1.3820 & 1.2864 & 1.8955 \\
\hline $\mathrm{Rb}$ & 0.0083 & 0.0056 & 0.0149 & 0.0581 & 0.0121 & 0.0161 & 0.0270 & 0.0544 & 0.0070 & 0.0067 & 0.0951 \\
\hline $\mathrm{Sr}$ & 2.0979 & 2.2675 & 2.4288 & 2.8381 & 2.4650 & 2.6572 & 2.7675 & 2.2781 & 3.2225 & 2.5774 & 3.3483 \\
\hline Cs & 0.0012 & 0.0014 & 0.0004 & 0.0023 & 0.0019 & 0.0015 & 0.0016 & 0.0023 & 0.0009 & 0.0011 & 0.0023 \\
\hline $\mathrm{Ba}$ & 0.1285 & 0.0431 & 0.0781 & 0.2136 & 0.3393 & 0.1319 & 0.1465 & 0.3971 & 0.0651 & 0.7019 & 0.3867 \\
\hline $\mathrm{Pb}$ & 0.0000 & 0.0000 & 0.0000 & 0.0000 & 0.0000 & 0.0000 & 0.0152 & 0.0000 & 0.0000 & 0.0000 & 0.0000 \\
\hline $\mathrm{Bi}$ & 0.0044 & 0.0035 & 0.0032 & 0.0030 & 0.0034 & 0.0035 & 0.0032 & 0.0029 & 0.0028 & 0.0035 & 0.0000 \\
\hline Th & 0.0021 & 0.0009 & 0.0026 & 0.0010 & 0.0040 & 0.0321 & 0.0020 & 0.0136 & 0.0011 & 0.0019 & 0.0194 \\
\hline $\mathrm{U}$ & 0.0000 & 0.0000 & 0.0000 & 0.0000 & 0.0000 & 0.0000 & 0.0000 & 0.0016 & 0.0121 & 0.0000 & 0.0023 \\
\hline
\end{tabular}

Notes: All data are reported as parts per million (ppm) normalized to water-free compositions using measured loss on ignition.

Table 9 (continued).

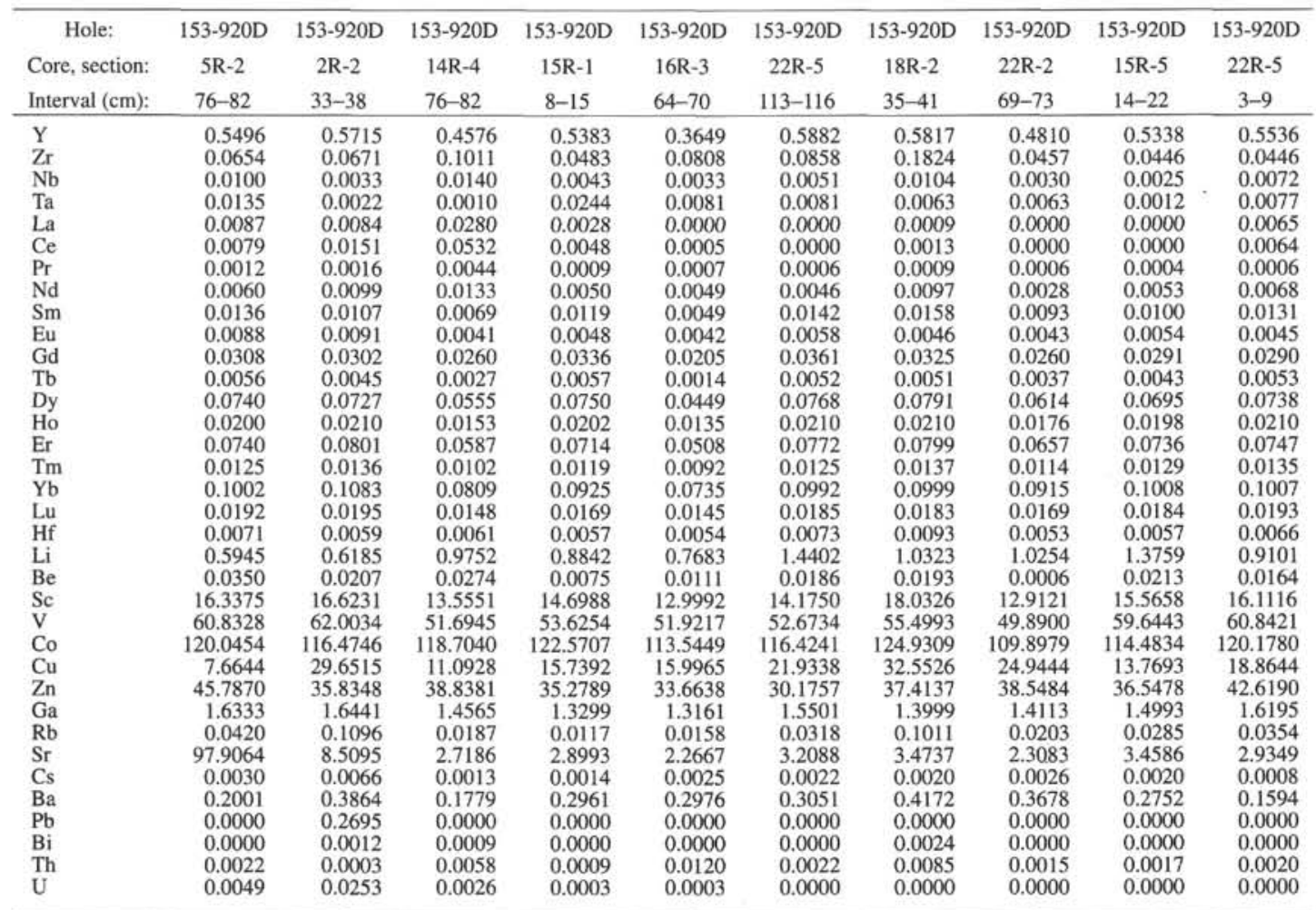


A

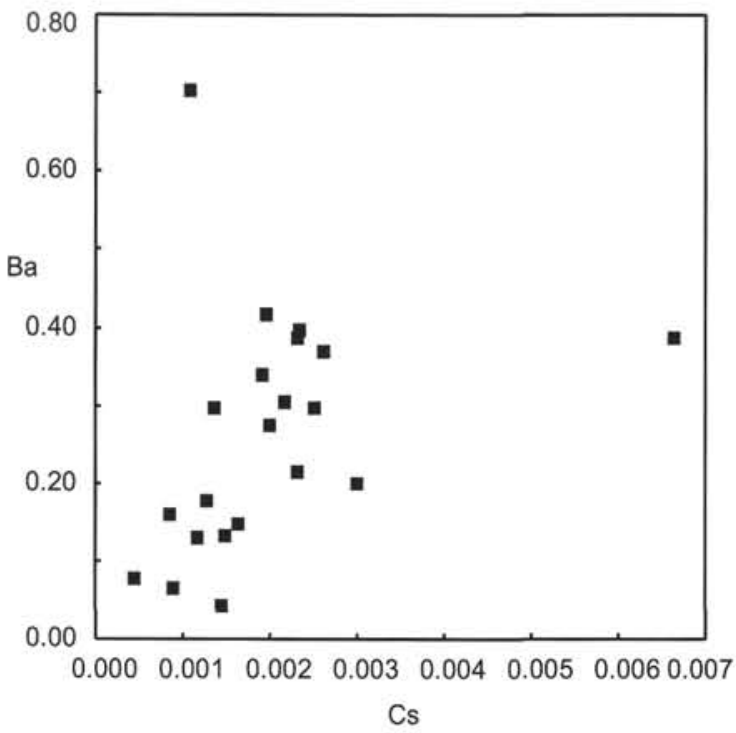

B

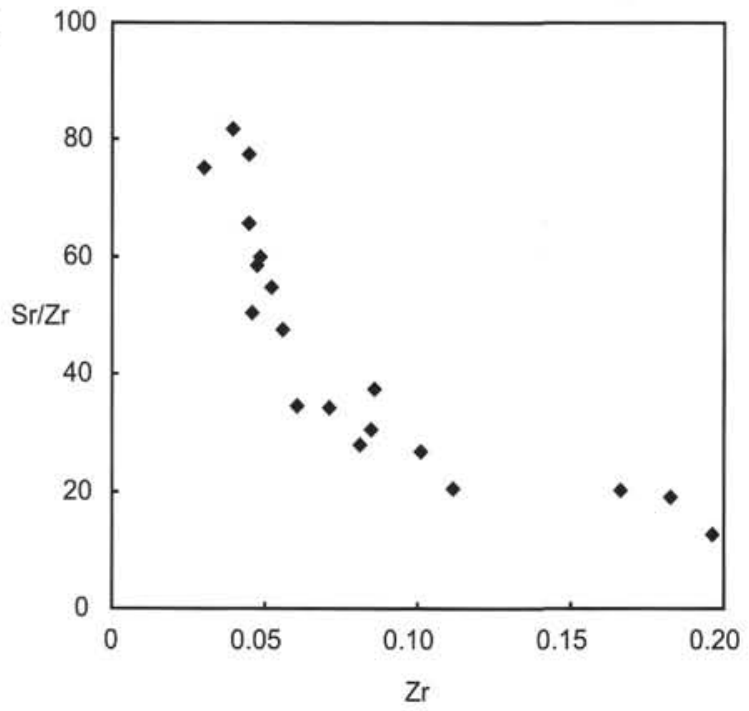

C

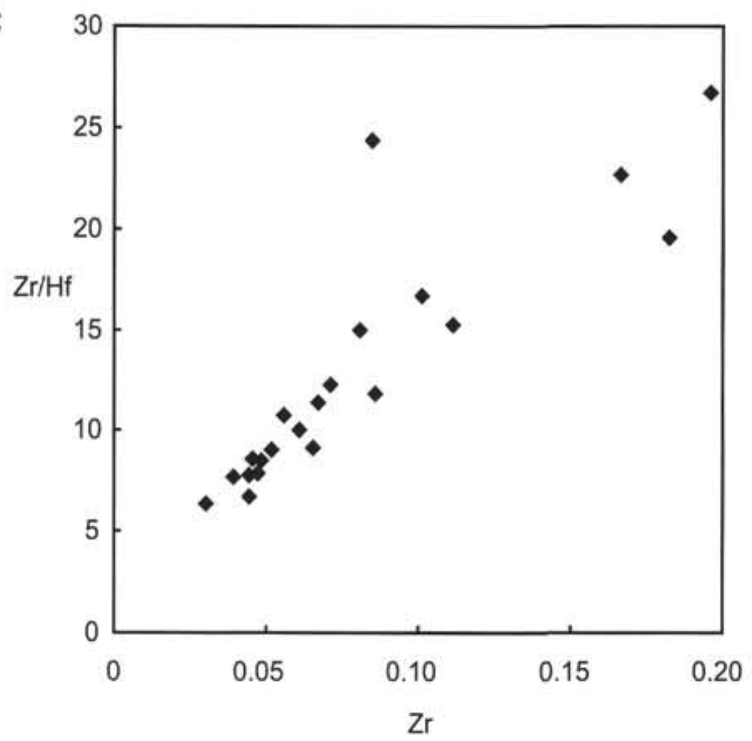

Figure 6. Trace-element compositions in Site 920 peridotites (in ppm) showing (A) good correlation between $\mathrm{Cs}$ and $\mathrm{Ba}$, suggestive of seawater alteration; (B) unusual correlation between $\mathrm{Sr} / \mathrm{Zr}$ and $\mathrm{Zr}$; and (C) decreasing $\mathrm{Zr}$ / $\mathrm{Hf}$ with decreasing $\mathrm{Zr}$. See text for discussion.
A

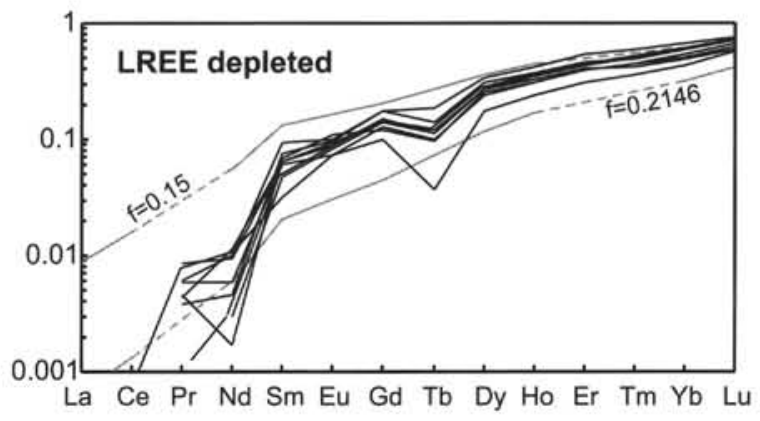

B

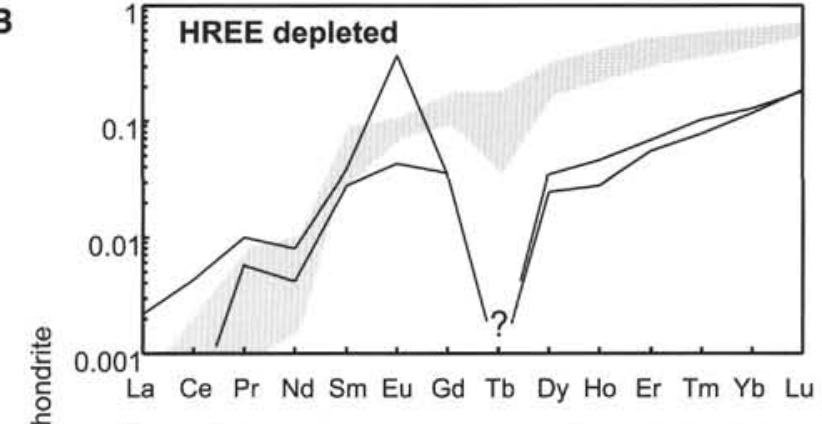

c

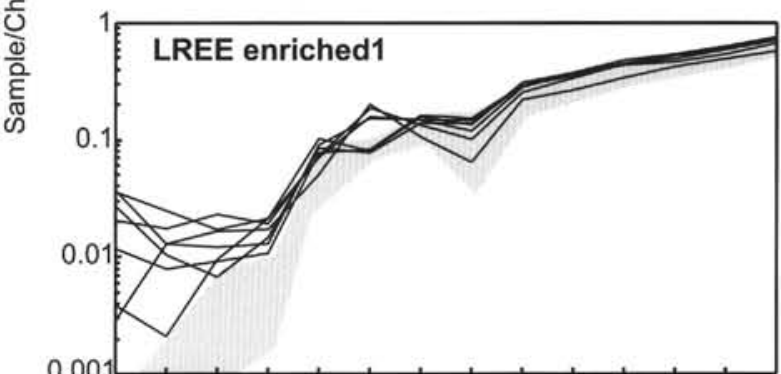

La Ce Pr Nd Sm Eu Gd Tb Dy Ho Er Tm Yb Lu

D

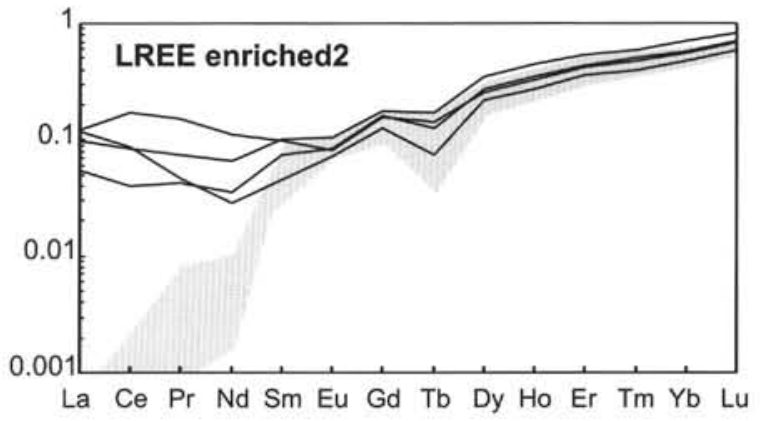

Figure 7. Subgroups of Site 920 peridotites on the basis of their chondritenormalized (Sun and McDonough, 1989) REE patterns. Lines marked $\mathrm{f}=$ 0.15 and $\mathrm{f}=0.2146$ on (A) are residual compositions for $15 \%$ and $21.46 \%$ fractional melting of fertile spinel peridotite from Ewart and Hawkesworth (1987). The range corresponds to less than 3 modal\% clinopyroxene at $\mathrm{f}=$ 0.15 to clinopyroxene exhaustion at $f=0.2146$. Shaded areas on (B), (C), and (D) indicate the range for LREE-depleted patterns from A. Subdivisions are discussed in the text. 
Hole 920B
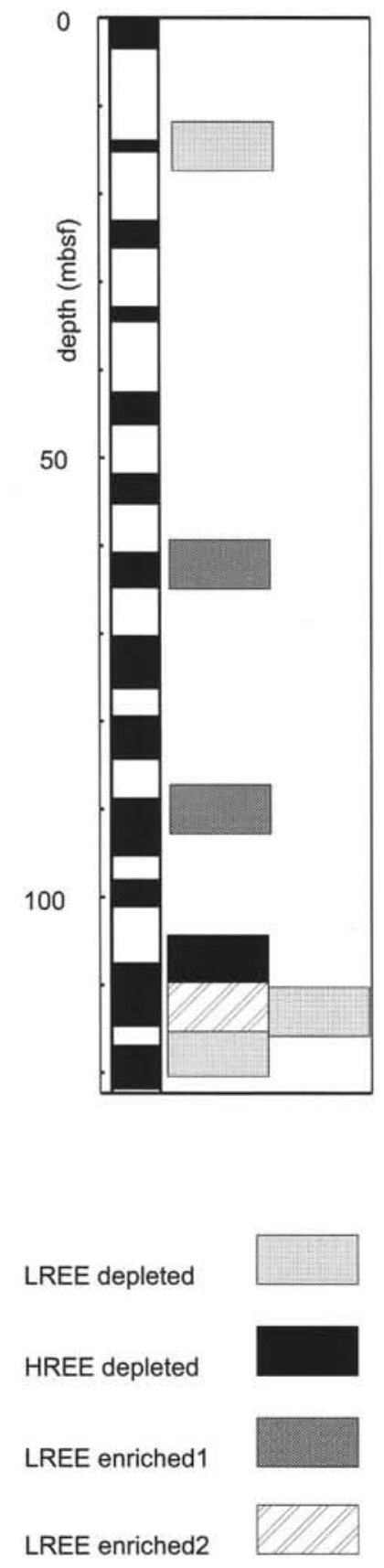

Hole 920D

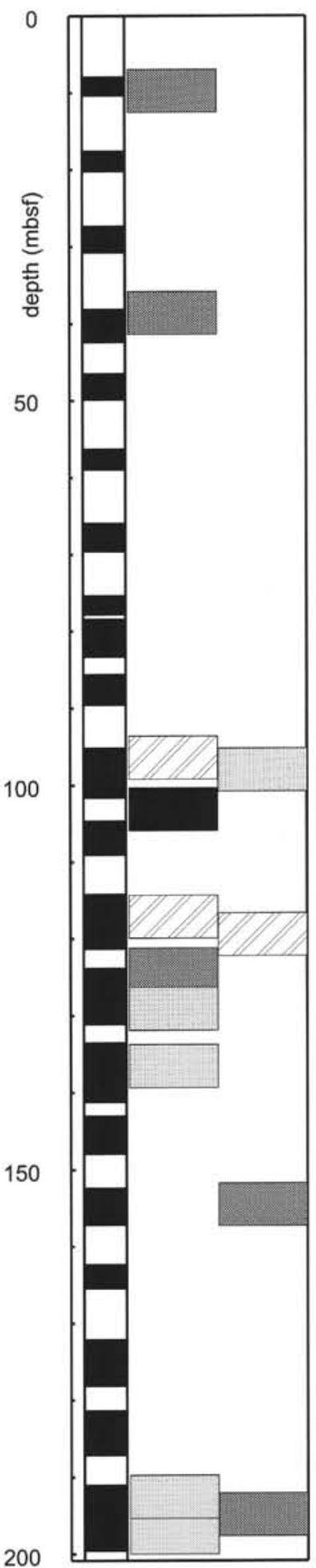

Figure 8. Distribution of individual samples in Site 920 drill holes based on their REE patterns, as defined in the text. 